\title{
Consequence of Paradigm Shift with Repeat Landscapes in Reptiles: Powerful Facilitators of Chromosomal Rearrangements for Diversity and Evolution
}

\author{
Syed Farhan Ahmad ${ }^{1,2}$, Worapong Singchat ${ }^{1,2}$, Maryam Jehangir ${ }^{1,3}$, Thitipong Panthum ${ }^{1,2}$ \\ and Kornsorn Srikulnath 1,2,4,5,6,7,*(D) \\ 1 Laboratory of Animal Cytogenetics and Comparative Genomics (ACCG), Department of Genetics, \\ Faculty of Science, Kasetsart University, 50 Ngamwongwan, Chatuchak, Bangkok 10900, Thailand; \\ farhan.phd.unesp@gmail.com (S.F.A.); worapong.si@ku.th (W.S.); maryam.bioinfo.unesp@gmail.com (M.J.); \\ thitipong.pa@ku.th (T.P.) \\ 2 Special Research Unit for Wildlife Genomics (SRUWG), Department of Forest Biology, Faculty of Forestry, \\ Kasetsart University, 50 Ngamwongwan, Chatuchak, Bangkok 10900, Thailand \\ 3 Integrative Genomics Lab-LGI, Department of Structural and Functional Biology, Institute of Bioscience at \\ Botucatu, São Paulo State University (UNESP), Botucatu 18618-689, Brazil \\ 4 Center for Advanced Studies in Tropical Natural Resources, National Research University-Kasetsart \\ University, Kasetsart University, Bangkok 10900, Thailand \\ 5 Center of Excellence on Agricultural Biotechnology (AG-BIO/PERDO-CHE), Bangkok 10900, Thailand \\ 6 Omics Center for Agriculture, Bioresources, Food and Health, Kasetsart University (OmiKU), \\ Bangkok 10900, Thailand \\ 7 Amphibian Research Center, Hiroshima University, 1-3-1, Kagamiyama, Higashihiroshima 739-8526, Japan \\ * Correspondence: kornsorn.s@ku.ac.th
}

Received: 26 June 2020; Accepted: 17 July 2020; Published: 21 July 2020

\begin{abstract}
Reptiles are notable for the extensive genomic diversity and species richness among amniote classes, but there is nevertheless a need for detailed genome-scale studies. Although the monophyletic amniotes have recently been a focus of attention through an increasing number of genome sequencing projects, the abundant repetitive portion of the genome, termed the "repeatome", remains poorly understood across different lineages. Consisting predominantly of transposable elements or mobile and satellite sequences, these repeat elements are considered crucial in causing chromosomal rearrangements that lead to genomic diversity and evolution. Here, we propose major repeat landscapes in representative reptilian species, highlighting their evolutionary dynamics and role in mediating chromosomal rearrangements. Distinct karyotype variability, which is typically a conspicuous feature of reptile genomes, is discussed, with a particular focus on rearrangements correlated with evolutionary reorganization of micro- and macrochromosomes and sex chromosomes. The exceptional karyotype variation and extreme genomic diversity of reptiles are used to test several hypotheses concerning genomic structure, function, and evolution.
\end{abstract}

Keywords: chromosome; genome; karyotype; sex chromosome; amniote

\section{Introduction}

Over 150 years ago, Darwin and Wallace first proposed the theory of natural selection requiring variation among species individuals and stable inheritance from generation to generation [1,2]. However, the mechanism of this variation remained unclear until Dobzhansky observed the occurrence of chromosomal changes among species in a Drosophila lineage [3]. It is these rearrangements 
that supplement the raw materials for evolution, thereby enabling populations to evolve rapidly under natural selection [4]. Evolutionary mechanisms include variation in chromosome size, composition, and number between and within species, which has been termed "stasipatric speciation" [5]. Such chromosomal variation is also associated with reproductive isolation and outbreeding depression [6-9]. Approximately 320 million years ago, amniotes diverged into two major lineages comprising Synapsida, including all living mammals, and Sauropsida, including all extant non-avian reptilian and avian species [10-13]. Extensive diversity in chromosomal changes is observed among different lineages of non-avian reptiles, and a chromosomal evolutionary model is required to elucidate the source, timing, and types of changes between species. Sauropsids include Archosauromorpha (birds, crocodiles, and turtles) and Lepidosauromorpha (tuataras and squamate reptiles). Higher chromosome variability is observed among squamate reptiles, which show substantial variation in chromosome numbers $(2 n=30-50)$. Their karyotypes can be categorized into two groups, consisting of those with few or no dot-shaped microchromosomes with an undetectable centromere, as found in Lacertidae and Gekkota, and those with macrochromosomes and many microchromosomes, as commonly observed in Scincoidea (skinks) and Episquamata (iguania, snakes, and monitor lizards) excluding Lacertidae [14-21]. A karyotype comprising a small number of macrochromosomes and many microchromosomes is also observed in birds and turtles [14,22-26]. By contrast, the karyotype of crocodiles is composed of chromosomes with a small number of large chromosomes and the absence of dot-shaped microchromosomes [8,27-31].

Chromosomal rearrangements often occur in combinations of different types as the source of karyotypic variation, and advances in omics technology enable elucidation of fine-scale changes in chromosome structure. Research interest has shifted from gross chromosomal rearrangements to smaller cryptic changes, such as segmental duplication and insertions/deletions [32,33]. These rearrangements can reshuffle genes, termed the 'position effect', through the location of regulatory elements and deletion of several genes or a portion of a single gene. Recent genomic sequencing projects involving several reptiles have led to an improved understanding of the substantial difference in proportions of genomic elements between functional genes and repeats [33-36]. Surprisingly, a similar number of genes is observed across amniotes, whereas different proportions and types of repeats are observed [37]. One emerging hypothesis is that a variety of chromosomal rearrangements are mediated through the transposition of interspersed repeats, such as transposable elements (TEs), and expansion of tandemly organized satellite sequences, which act as catalysts to drive genome evolution [20,21,26,29,36,38-46]. The correlation between repeats and chromosomal rearrangements must be investigated in the context of the diversity and evolution of reptilian lineages. To date, genome-wide characterization of repeats ('repeatomics') has focused on certain animal groups, such as mammals [47,48], with scant attention given to reptilian genomes [49]. Following completion of the first two mammalian genome sequencing projects involving mouse and humans [50,51], a decade passed before publication of the first reptilian genome, that of the green anole (Anolis carolinensis) in 2011 [52]. In this modern era of next generation sequencing (NGS), the number of sequenced mammalian genomes is considerably greater than that of reptiles, although the total number of reptilian species is almost four times higher than that of mammalian species [53]. However, genomic assemblies for several reptiles are in progress, which will provide novel resources for high-throughput repeatomic analyses of diverse lineages [49]. As of May 2020, the National Center of Biotechnology Information genome database included 64 publicly available assembled genomes (https://www.ncbi.nlm.nih.gov/genome/?term=reptiles), and this number is expected to rise rapidly. This advance has heralded renewed interest in several questions that link reptilian genomes and repeats, including (i) how does the proportion of repeats in the reptilian genome differ from that of other amniotes, (ii) in which specific genomic repeats do reptiles differ from other amniotes, (iii) how do genomic repeat contents differ among reptilian lineages, (iv) what potential mechanisms affect karyotypic evolution in reptiles through genomic repeats, and (v) is repeatomic diversity correlated with the extensive chromosomal variation seen in reptiles. Here, we review evidence pertaining to different repeat profiles in reptiles obtained from molecular cytogenetics and 
comparative genomics research. We highlight data for key species and present a comparative overview of repeat landscapes in different reptilian lineages. The dynamics of repeat-mediated rearrangements and their evolutionary impact on reptilian genome reorganization are discussed.

\section{Diversity of Repeats in Reptiles Versus Other Amniotes}

Amniotes exhibit substantial variation in genomic composition, structure, and size; however, the number of protein-coding genes is similar across diverse amniote lineages [37]. Important features that contribute to such genomic variation are the diversity and different proportions of TEs $[37,54,55]$. Transposable elements, collectively termed the 'mobilome', constitute the major portion of the genome and are capable of self-replication and/or multiplication [56]. Transposable elements play an important role in genome evolution and contribute to a variety of genetic novelties, such as gene regulation for reshaping phenotypic diversity in the lineage $[57,58]$. Long terminal repeats (LTRs) and SINE-VNTR-Alu retrotransposons affect functional gene expression in primates and drive evolutionary divergence [58]. By contrast, TEs can have certain detrimental effects on the host genome as a result of direct insertions in functional genes or indirectly through non-homologous recombination $[59,60]$. Although amniotes contain the majority of known eukaryotic TEs, substantial variation in copy number, nucleotide sequence, and evolutionary age have been identified among lineages [55,61]. Transposable elements constitute a higher proportion of mammalian, squamate reptile, and turtle genomes compared with that of avian genomes (Figure 1). Whole-genome repeat annotations in birds and mammals indicate 1.7- to 2.2-fold variation in number of TEs among species [37]. Mammalian genomes differ substantially in TE diversity and abundance from the ancestral amniote genome [54,55] Certain TEs comprise both autonomous endogenous retroviruses (ERVs), LINE1, Tc-Mariner, or hAT DNA and non-autonomous V-SINE, which are commonly expanded in all amniote genomes [62]. This observation suggests the existence of these TEs in ancestral amniotes. By contrast, several types of TEs have been lost in specific taxa, for example the absence of the Gypsy TE in avian and mammalian genomes [63,64]. Transposable elements are generally scattered throughout the genome $[65,66]$ however, the majority of TEs are abundantly distributed in specific chromosomal regions, such as genomic regions corresponding to G-banding patterns in mammalian species [67], or on sex chromosomes such as LINE1 TEs in mammals, birds, and reptiles [64].

Apart from TEs, a high proportion of amniote genomes are satellites that represent large copy number elements arranged tandemly in the heterochromatic region on chromosomes. Satellites can be categorized into different types/families or subfamilies based on the sequence length, structure, organization (including higher-order repeats), and chromosomal localization [36,41,42,44,68,69]. Multiple satellite families are present in a species, but the abundance of families often differs, resulting from the influence of library models with species-specific amplification under selective force [68]. The majority of satellites exhibit a high mutation rate and capability for rapid evolution, and the sequences are highly variable and often clustered as species- or genus-specific satellites as observed in crocodiles, turtles, lacertids, varanids, and snakes [12,29,36,40,69-71]. A general assumption about satellite expansion in the genome involves a cohesive evolutionary concept owing to intraspecific homogenization (or concerted evolution) [72,73]. However, satellites with slow mutation rates are present in many snakes and varanids, resulting in a lack of species-specific homogenization $[36,70]$. Satellite sequences are shared among closely related species, which indicates that the homogenization rate is slower than species divergence mechanisms. The most recent advanced genome-scale investigation of satellites, predominantly microsatellites, has revealed an astonishing abundance in squamate reptile genomes [61,74]. Certain snake species, mainly colubrid snakes, contain higher abundance of overall repeats in their genomes as well as the highest density of microsatellites across all studied squamates [61,75] (Figure 2), in accordance with the amplification of microsatellites on sex chromosomes [20,39,69,76-81]. Remarkable variability of microsatellites among the main amniote groups, such as reptiles and mammals, has been previously reported $[52,74,82,83]$ Recent 
studies have revealed high levels of microsatellite variability within reptile lineages, such as snakes and other squamate reptiles [61] (Figure 2b).

(a)

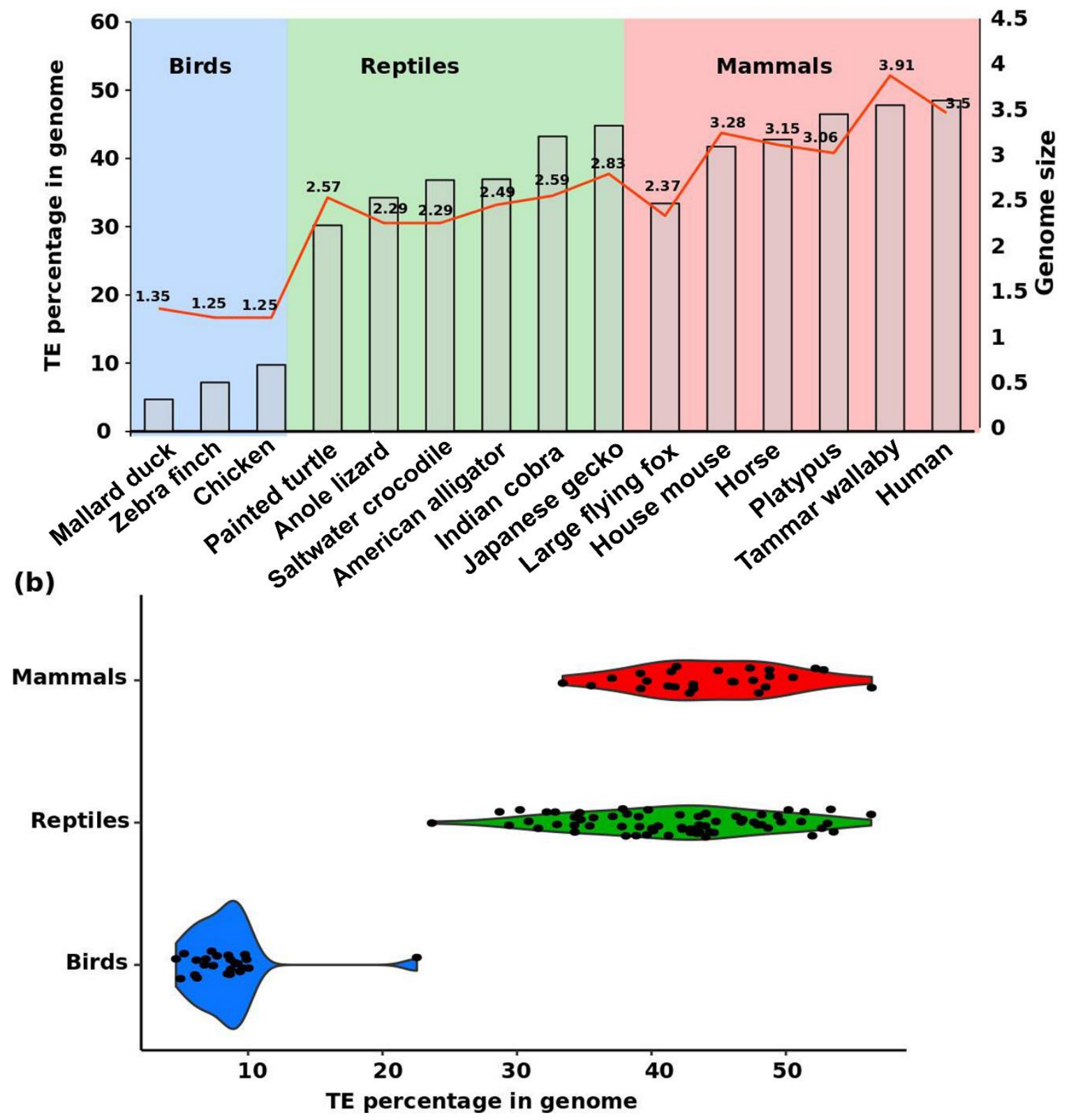

Figure 1. Percentage of transposable elements (TEs) in the genome representative amniotes. The bird genome contains the lowest percentage of TEs and genome size compared with the genomes of mammals and reptiles. (a) Bar chart shows the TE percentage of different birds (blue), reptiles (green) and mammals (red) and the red line indicates the genome size. (b) Distribution of total TE percentage in the genome of different species across reptiles, mammals and birds. Each dot represents a species. The species list is given as Supplementary Dataset S1. 
(a)

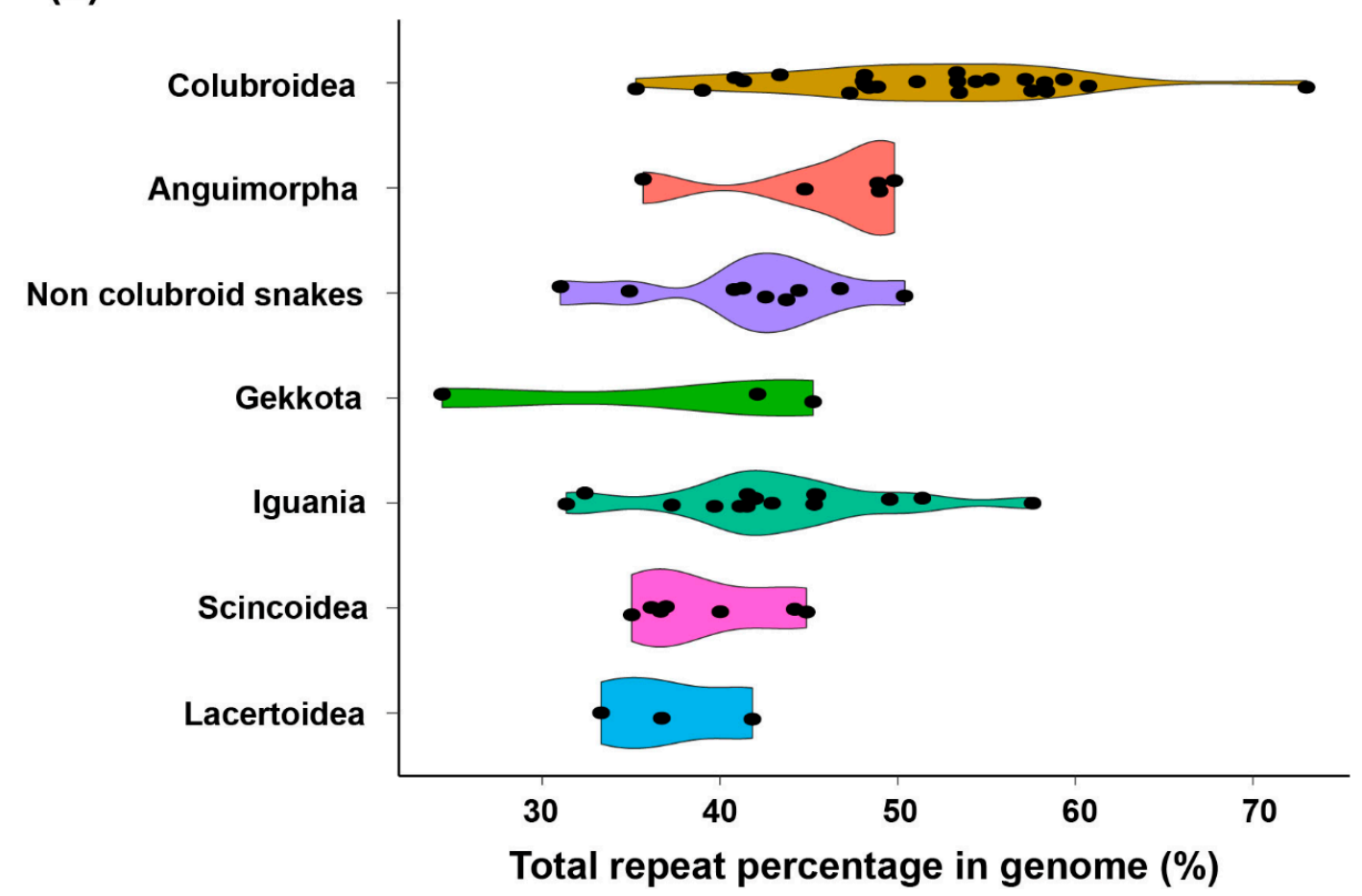

(b)

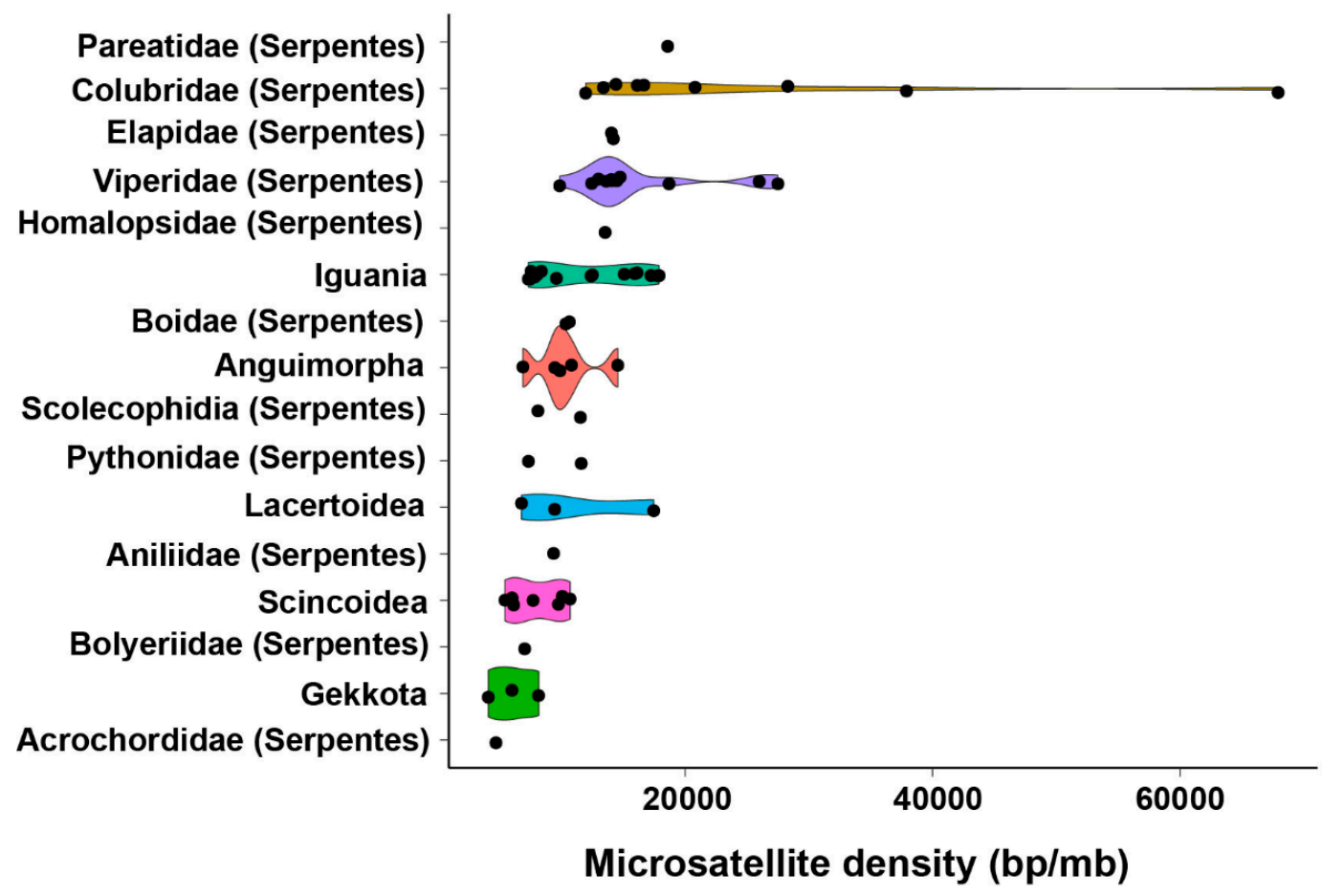

Figure 2. Percentage of total genomic repeats in diverse lineages of squamate reptiles. Violin plots highlighting the family-wise distribution of total repeat proportion (a) and microsatellite density (b) in genomes. Each dot represents a single species. The species list is given as Supplementary Dataset S1.

Repeat contents of $28 \%$ to $58 \%$ are reported for mammalian genomes [84], whereas avian genomes are more compact with repeat contents of approximately 15\% [85], which suggests that amniotes show 
a significant diversity of repeats (Figure 1). Current understanding of repeats and genome evolution of amniotes is biased considerably towards mammals and birds. Mammalian genomes differ from other amniotes in the unique diversity of TEs and abundance of specific elements [64]. In addition, genomes of birds and reptiles show remarkable variety of TEs, most probably derived from the amniote ancestor, whereas limited differences have been observed across major reptilian lineages. Squamate reptiles exhibit a higher degree of repeat variation compared with birds, whereas overall abundance is indicated to be lower than in mammals. Repeat landscapes in squamate reptiles can differ remarkably, even among species within the same genus, with different variation rates, e.g., within the genera Ophisaurus (44.8-48.9\%), Coniophanes (59.4-73\%), and Crotalus (35.3-47.3\%) [36]. The overall repeatomic variation ranges from $24.4 \%$ to $73.0 \%$ (three-fold variation) in squamate reptiles [61]. It would be interesting to determine repeatomic variation ranges in other amniote groups, such as turtles and crocodiles, and the extent of variation at species and genus levels. Significant advances are possible through large-scale species sequencing and genome assembly.

\section{Dynamics of TE and Satellite Landscapes in Different Reptilian Lineages}

Reptile genomes show great considerable TE diversity, with TE family abundance ranging from $23 \%$ to $53 \%$ within species [49,61] (Figure 1b). The anole lizard mobilome displays extraordinarily diversified TE families annotated as young copies of ancient elements [52,64,86] (Figure 3b). This finding is at odds with avian and mammalian genomes, which show relatively higher enrichment of ancient elements, and suggests that the anole genome underwent an extreme level of recent dispersion of TE insertions [64] (Figure 3). Class I TEs, which are mobilized through retrotransposition mechanisms, represent about 43 families in the anole genome [87-89]. In addition, a broad variety of class II TEs do not require a RNA intermediate for movement in the anole genome. These class II TEs are subdivided into several autonomous groups, such as hAT, Mariner, and Helitron, which are indicated to be recent insertions [90]. Three additional TE forms are either extinct (Chapaev) or present in extremely low proportions of the genome (PIF/Harbinger and Polinton/Maverick) [88]. Comparison of TE evolutionary age between snakes and the anole reveals that TEs in snakes are probably older than those of the anole, although earlier expansions of TEs, such as snake1, CR1, LINEs, and BovB, in colubrid snakes were suggested [82,83]. Insertions of TEs, such as hAT-Charlie, Tc1/Mariner, and Gypsy, have also been reported in snake viper genomes, and L2 and CR1 TEs have been detected in boas and pythons [91]. Abundance and diversity of TEs vary considerably among species of archosaurs, especially in birds and crocodiles, and also perhaps in dinosaurs [92-94]. Crocodilian genomes possess comparatively higher abundances of TEs than those of birds, which suggests that the former are more similar to archosaur genomes $[92,93,95]$. Although TE contents vary significantly between crocodilians and birds, CR1s comprise the largest proportion of TEs in both groups $[85,92]$. CR1 TEs constitute approximately $2-7 \%$ of the majority of bird genomes and about $10 \%$ of crocodilian genomes $[85,92]$. Crocodilian genomes also consist of large proportions of other TEs, such as hAT and PIF/Harbinger (7\%) and Gypsy (3\%) elements [93]. It is hypothesized that the CR1s, ERVs, and SINE activities may contribute to crocodilian diversification $[62,96,97]$. Apart from crocodiles, understanding the mobilome of turtles has been a focus of research for the past three decades [98]. Recent research has shown that different interspersed elements may share retropositional machinery by exchange of sequence fragments [99]. Although earlier discoveries have shed light on the types of TEs in this monophyletic group, the diversity and level of variation among species remain poorly understood. Recent genomic analysis reported that $10 \%$ of the turtle genome may constitute TEs $[34,64,100]$. Turtle genomes also include CR1/L3 as the most abundant elements of TEs [64,101]. Several CR1 subfamilies have been identified in the turtle genome, exhibiting a lower percentage variation than the consensus sequences, which is indicative of recent expansion of these elements in the turtle lineage [101]. 
(a)

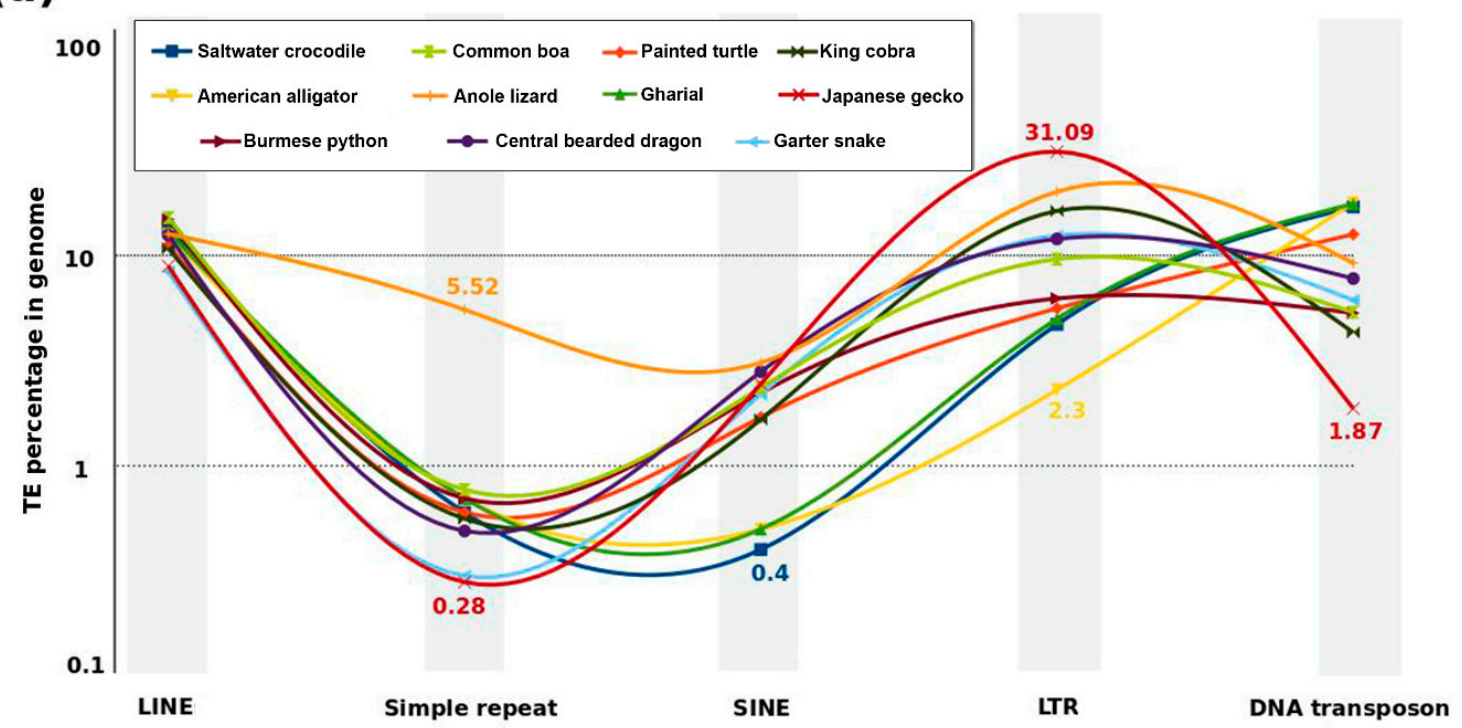

(b)

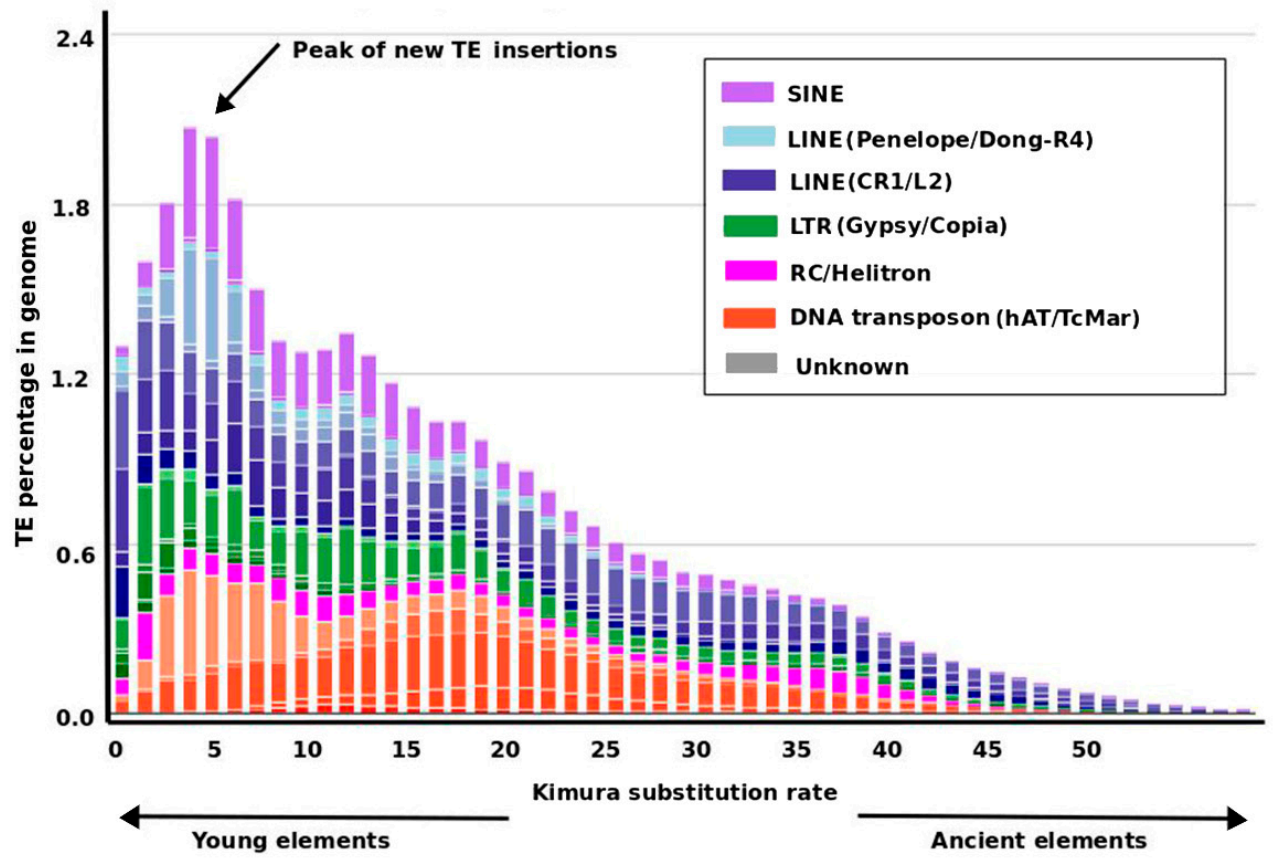

Figure 3. Genomic proportion of repeats in reptiles. (a) Comparative line plot of major repeat elements in 11 representative species. The proportion of LINEs is similar for each species, whereas Anolis shows the highest abundance of simple repeats. LTRs are most abundant in gecko and least abundant in alligator. Crocodile, gharial, and alligator show similarly low abundance of SINEs. The X-axis has no intrinsic meaning for variable values and is given to represent the types of repeats only. A bar graph of the same data is provided as Supplementary Figure S1. (b) Transposable element (TE) evolutionary landscape of the Anolis genome. The $y$-axis and $x$-axis represent genomic proportion (\%) and Kimura divergence, respectively. A recent wave of transposition in the Anolis genome has occurred, as indicated by the black arrow and very low proportions of old elements. K values from 1 to 50 denote evolutionary divergence from younger to older repeats. Data for the percentage of repeat elements was sourced from the literature and the RepeatMasker database (http://www.repeatmasker.org/genomicDatasets/RMGenomicDatasets.html, last accessed, June 2020). The Anole TE landscape was retrieved from RepeatMasker and manually annotated and edited using Inkscape V 0.92 (https://inkscape.org/release/inkscape-0.92/). 
Satellite diversity and abundance are difficult to identify because of repeat complex structures $[43,46]$. Satellites have been examined in only a small number of reptile species, and knowledge of satellite structure and evolution remains limited. Several studies have focused on chromosome mapping of microsatellites in reptiles [20,45,102], in which the majority of microsatellites were distributed on sex chromosomes. Snakes represent an interesting model to expand our knowledge concerning the evolution of centromeric satellite DNA. Three different types of heterochromatic region-linked satellite families are found in the Burmese python and habu snakes [69]. These satellite families include (1) PFL-MspI (168 bp) from Protobothrops flavoviridis, (2) PBI-DdeI (196 bp), and (3) PBI-MspI (174 bp) from Python bivittatus. Thongchum and co-workers [36] studied 40 snake species to gain an improved understanding of the conservation of PBI-DdeI satellite evolution and function. Their results indicate high variation in copy number between P. bivittatus and other snakes. The PBI-DdeI satellites identified in scaffolds account for approximately $0.353 \%(5.070 \mathrm{Mb})$ of the P. bivittatus genome, which differs from the copy number estimated by quantitative PCR of approximately $5.73 \times 10^{6}$ copies accounting for $82.53 \%$ of the genome [36]. This specific satellite is not identified in any of the genome sequences for snakes, although the PCR approach has successfully detected satellites of many snake species. This suggests that these scaffolds are derived from the centromeric region but are not yet anchored to chromosomes, which reflects the difficulty of sequencing and assembling repeat-rich chromosomal regions. Interestingly, PBI-DdeI satellites are frequently localized to the W sex chromosome of Naja kaouthia. Localization of high copy numbers in female rather than male individuals suggests that PBI-DdeI might act as an evolutionary driver with several repeats and facilitate $W$ chromosome differentiation and heterochromatinization $[20,21,36]$. Satellites have been extensively studied in lacertids [103-111], scincids [102,108], and varanids [40,70]. All satellites studied were localized to chromosomal heterochromatin and predominantly in centromeric, pericentromeric, and/or telomeric regions. In Lacertinae, five satellite families, each with a specific phylogenetic distribution, have been identified. Three of these satellite families are genus-specific, i.e., pLHS in Podarcis [104], CLsat comprising three subfamilies in Darevskia [112-114], and Agi160 in Lacerta [106,107]. By contrast, the remaining two families are widely distributed in Lacertinae. The satellite pLCS is shared among Algyroides, Teira, Lacerta, and Podarcis $[103,115]$, and pGPS is present in Podarcis, Archaeolacerta, Algyroides, Lacerta, and Zootoca [105]. Giovannotti et al. [108] reported that two satellite families are present in the four species of Iberolacerta as (i) the centromeric HindIII family, containing two subfamilies (I and II) representing 5-10\% of the genome, and (ii) the TaqI family, possessing only interstitial sites with $2.5-5 \%$ of the genome. Differences in abundance, chromosomal position, and evolutionary rate were observed for the HindIII and TaqI families across lacertids. One novel AAN-TaqI satellite with an AT-enriched monomer of 187-199 bp was isolated from populations of Atlas dwarf lizard (Atlantolacerta andreanskyi) [110]. This sequence is predominantly localized to the subterminal regions of the short arms of all chromosomes. In Lacerta, certain satellites, such as IMO-TaqI, are abundant within heterochromatic regions of the $\mathrm{W}$ sex chromosome, which indicates that this repeat may be involved in heterochromatinization and sex chromosome differentiation $[109,111]$. In varanids, the VSAREP satellite has been identified in water monitor (Varanus salvator macromaculatus) and is conserved in the genomes of Asian and Australian varanids but not in African varanids [40,70]. This satellite family is considered to play an important role in chromosomal rearrangement in varanid lineages [70]. In addition, the satellite families CSI-HindIII and CSI-DraI isolated from the Siamese crocodile (Crocodylus siamensis) were characterized in the crocodile genome, which indicates their localization in the heterochromatic blocks of centromeres [29]. The CSI-HindIII family is conserved across all extant crocodile lineages of Crocodylidae, Gavialidae, and Alligatoridae. This conservation indicates the possible presence of the CSI-HindIII sequence in the karyotype of a common ancestor of Crocodylia. By contrast, the CSI-DraI satellite is known only in Crocodylus and is not represented in other crocodile genomes. This specific occurrence suggests rapid evolution of CSI-DraI and offers insights into how the Crocodylus lineage might have diverged from Tomistoma and Gavialis $[8,29,116,117]$. In the Chinese soft-shelled turtle (Pelodiscus sinensis, Trionychidae), a novel satellite designated PSI-Bgl 
was cytogenetically characterized and mapped on microchromosomes in the centromere regions and satellite arms but was not detected on macrochromosomes [71]. This site-specific satellite compartmentalization pattern is also observed in the Mexican musk turtle (Staurotypus triporcatus) and the giant musk turtle (S. salvinii) [118], and suggests that size-specific compartmentalization might have occurred in turtles and also in birds but not in squamate reptiles $[24,40,70,119]$. Taken together, these recent advances in identification of repeats in reptilian genomes provide a solid foundation for further investigation. To augment knowledge of the dynamics and comparative landmarks of repeats, further in-depth studies are required to understand how the scale of variability of these elements drives genome evolution and how such variation affects processes such as gene regulation, sex chromosome evolution, and karyotype reorganization among reptilian lineages.

\section{Evolutionary Impact of Repeats in Reptiles: Mediators of Chromosomal Rearrangements to Drive Genome Reorganization}

A simple approach is to consider that genome reorganization and chromosomal changes are caused by TE insertions and are mediated through variation in TE copy number throughout the genome and in the species-specific repertoire [84,120]. Such variation is observed in the genome size and structure. Transposable elements are considered to play an important role in the genomic variation among amniotes [64,121-123]. These genomic changes are more extensive where these elements can contribute significantly to an increase in genome size, especially in mammals [84]. By contrast, the dynamics of repeats in squamate reptiles challenge the paradigm and existing concept of co-evolution between repeat abundance and genome size [61]. A phylogenetic survey of 84 species comprising five different groups including crocodiles, turtles, tuatara, lizards and snakes showed diverse genome sizes and chromosome numbers (Figure 4), possibly linked with high dynamism of repeats in the reptilian genome. In addition to genome size, TE mobilization and amplification of copy number can affect genome reorganization via non-homologous recombination, leading to diverse types of chromosomal rearrangements, including deletion, inversion, duplication, and translocation, or the emergence of neocentromere and centromere repositioning. This can result in changes in the host genome and diversity at the individual, population, or species level as a consequence of postzygotic reproductive isolation mechanisms $[9,124]$. In turn, this prevents the formation of fertile offspring through hybrid unviability, sterility, and/or breakdown after fertilization caused by differences in karyotypes and/or chromosome structure between the parental species, resulting in meiotic arrest and subsequent apoptosis of gametocytes $[9,125,126]$. In a broader context, TE-induced rearrangements contribute to lineage-specific evolution by inducing chromosomal-scale variation, regulation, or mutation of genes, ultimately leading to participation in speciation [127-130]. A relationship between TE expansion and species divergence has also been hypothesized in mammalian groups, including rodents and bats [51,131-133]. Although there is no direct evidence for chromosomal changes mediated by TEs in reptiles $[133,134]$, the incredibly diverse landscape of repeats in reptiles offers potential evidence for prediction of these phenomena under the impact of TE-mediated rearrangements. Multiple independent horizontal transfer (HT) events and peculiar TE patterns may have resulted in extreme genome variation in squamate reptiles [135]. This combination of high-scale transposition and chromosomal rearrangements acted as the major evolutionary force to produce the remarkable species richness and population diversity in this group [14]. The expansion of TEs in a genome may have contributed to the reduced speciation rate in lineages with a large genome size compared with that of lineages with a smaller genome size [136]. Mechanisms of TE accumulation in distinct genomic regions must be understood to explain the role of TEs in evolution. Satellites can also contribute to genome reorganization, such as chromosomal structural changes and heterochromatinization [137]. Centromeric CSI-HindIII identified in the Siamese crocodile is observed on all chromosomes except chromosome 2 [29]. However, linkage homology and the gene order of Siamese crocodile chromosome $2 p$ and the proximal region of $2 q$ are highly conserved with the chicken $\mathrm{Z}$ chromosome and squamate reptile chromosome $2 \mathrm{p}$ [28]. This might result from centromere repositioning in the Siamese crocodile, 
leading to the formation of neocentromeres and new centromeric satellites specific to chromosome 2 . Although satellites are critically associated with chromosome structural changes, many satellite families exhibit substantial sequence variation among phylogenetically related taxa. Such dynamics can result in acceleration in the rate of mutation and the formation of tandem arrays within a short evolutionary period, leading to speciation $[70,138,139]$. It is likely that satellites have been continuously linked with fragile sites and/or evolutionary breakpoint regions (EBRs) in various lineages, and associated with frequently occurring chromosomal rearrangements, such as Robertsonian translocation, centric fusion or fission, tandem fusion, and inversion [45,70,140-146]. Such dynamic behavior of satellites to modulate genomic architecture can be crucial to the promotion of rearrangements. A growing number of studies have provided evidence concerning the role of satellites in reorganization of the genomic architecture and decoding a variety of functions that may link the dynamic nature of these repeats to genome plasticity and evolution [147]. A rapid increase in copy number and divergence of satellites may have contributed to genome evolution through reorganization derived from chromosomal rearrangements [148]. As an example, in reptiles, the genome of rock lizards Iberolacerta harbors the HindIII centromeric satellite repeat. This satellite has been linked with chromosomal rearrangements, such as recombination events, which can act as a major evolutionary force in the formation of new repeat monomers, with faster rates of homogenization causing rapid shifts in centromere sequences, triggering species radiation in this lineage [111]. Both TEs and satellites are regarded as crucial actors and as "engines" that trigger genome evolution in reptiles. Genomic regions enriched with such repeats may function as "hotspots" or "fragile-sites" to facilitate rearrangements and drive lineage- or species-specific structural genomic changes that result in phenotypic variation $[57,140,143,149,150]$. This may also account for the variation responsible for the evolutionary success of amniotes. 

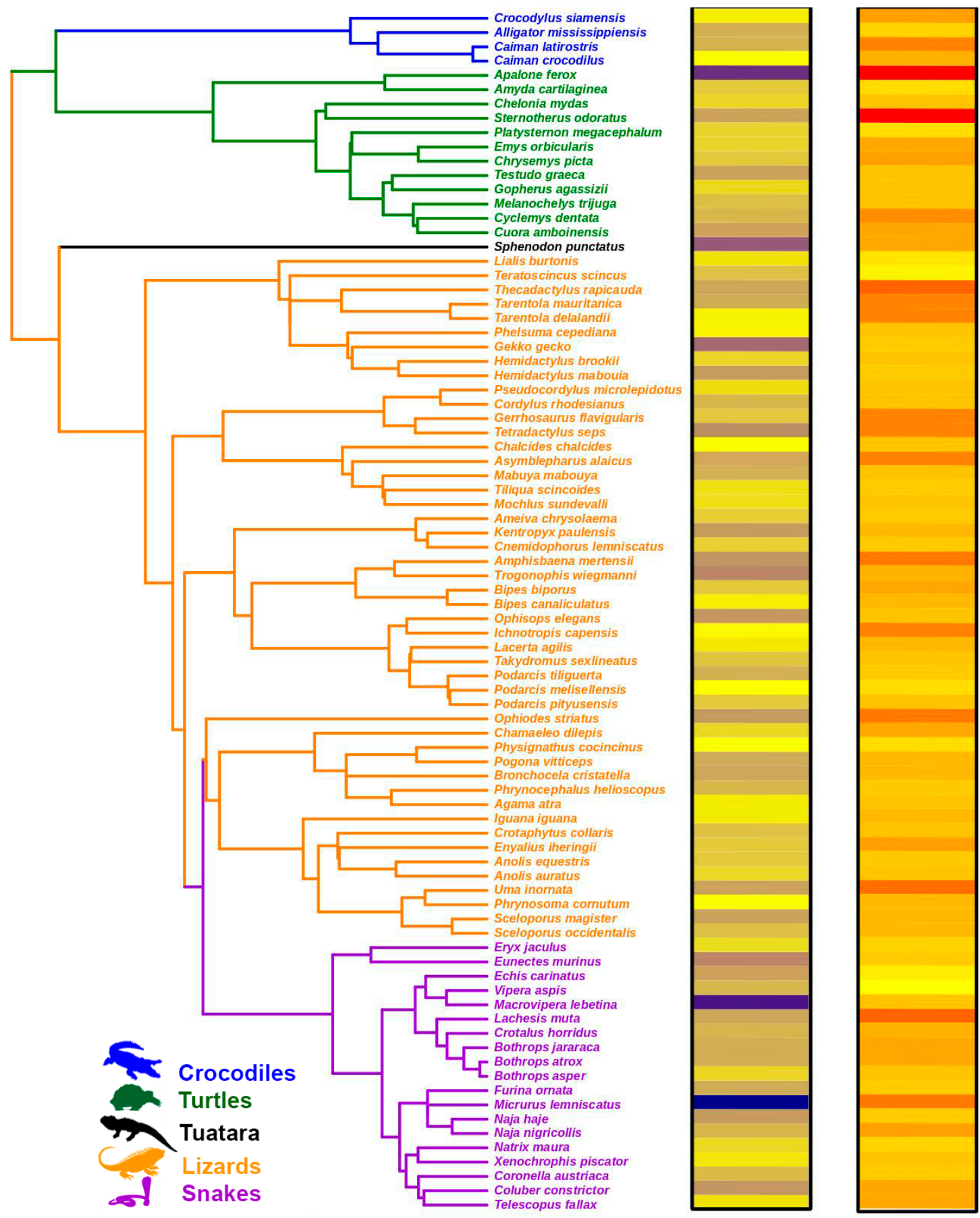

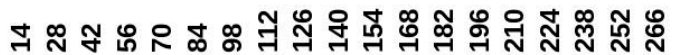

Million years ago
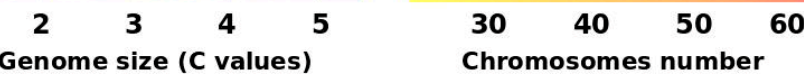

Figure 4. Phylogenetic relationships of 84 reptile species highlighting all families. Chromosome number and genome size were plotted as heatmaps in R using customized script for each corresponding species. The tree topology was retrieved from the TimeTree online database (http://www.timetree.org/). Chromosome number and genome size data were sourced from the animal genome database (https: //www.animalgenome.org). Genome size and actual number of chromosomes for each species is listed as Supplementary Dataset S2. 


\section{Repeatome and Genome Complexity with Evolutionary Breakpoint Regions}

Chromosomal rearrangements are the driving force of chromosome evolution in reptiles, particularly in squamate reptile genomes that exhibit substantial karyotypic variation $[14,151]$. Crocodile and turtle genomes show lower chromosomal variability and compartmentalization, which might have limited the rearrangement frequency and recombination rate. This lower chromosome variability accounts for the limited change in linkage homology and has maintained the set of genomic elements, and even gene order, although large numbers of microchromosomes are observed in turtles [152,153]. Squamate reptile genomes may thus have acquired smaller chromosomes but retained higher dynamic reorganization [19]. Combination of chromosome painting information with gene mapping and whole-genome data permits us to reconstruct the ancestral karyotype [154-158]. This involves comparison of chromosomes over evolutionary time across amniotes to understand the most likely direction of chromosomal rearrangement in a common ancestor. The tracing of such events can provide insight into evolutionary processes and the role of chromosomal rearrangements in phenotypic evolution and diversity, probably associated with species richness in squamate reptiles [159]. Common types of "gross" chromosomal rearrangement (usually several megabases long) can be detected at the microscope level, such as deletions, inversions, duplications, and translocations (centric fusion and fission, Robertsonian translocation, reciprocal translocation, tandem fusion, terminal transposition, and insertion), although the majority of rearrangements involve multiple fusion [15-21,28,38,153,160]. Different types of chromosomal rearrangements are involved with structural variation at the scale of the genomic region, ranging from a portion of a single gene to hundreds of genes [161]. Lineage-specific patterns are also observed as centric fusion and fission and tandem fusion, which is common in crocodiles, whereas multiple fusions occur in squamate reptiles [8]. Chromosome morphology can be altered by pericentric inversion that involves breakpoints at different distances on either side of the centromere, or by centromere repositioning, whereby a neocentromere occurs on a chromosome arm without alteration of the gene order [162]. A strong correlation probably exists between EBRs and repeats (TEs, satellites, microsatellites, and multiple gene families) [163,164]. Recently, chromosome-scale assemblies have enabled mechanistic insight into EBRs and intra-chromosomal rearrangements in avian genomes (saker falcon [Falco cherrug], budgerigar [Melopsittacus undulates], and ostrich [Struthio camelus]) [158]. It is necessary to extend these data further for highly rearranged reptilian genomes at such resolutions. While certain chromosomal rearrangements can mostly be induced by repeats through non-homologous recombinations, other rearrangements are associated with unstable genomic regions [165]. Rearrangement polymorphisms in reptiles are correlated with phenotypic differences, which might naturally confer varying fitness in different geographies [166,167].

Such tandem repeats are highly enriched at telomeres and are considered necessary to maintain genomic stability by protecting telomeric regions from degradation $[15,19,45,146,168,169]$. Apart from their localization at telomeres, these repeats might be embedded within internal sites to form interstitial telomeric sequences, which have been detected in amniote genomes and are considered to be byproducts of ancestral chromosome fusion [170], and are predominantly co-localized with induced chromosome breakage [171-173]. Such sequences can trigger genome instability, reshuffling the genomic architecture via different types of chromosomal rearrangements caused mainly by fusion, fission, inversions, or translocations $[12,15,20,21,141,146,174]$. Interstitial telomeric sequences are considered to be hotspots of chromosome breakage [170] and have been observed in multiple reptile lineages $[8,15,20,29,45,77,146,175]$ associated with chromosomal rearrangements. Repeats might be seeded by transposition or by integration between break-ends from other genomic positions during non-homologous end-joining, an erroneous variant of double-strand break repair. Nucleolus organizer regions (NORs) are highly polymorphic and well known for their potential intragenomic mobility [176]. It is unclear whether unequal recombination or transposition are responsible for this mobility in sex chromosomes of Chinese softshell turtle (Pelodiscus sinensis), S. crassicollis, S. triporcatus, and S. salvinii $[28,118]$. Notably, a common observation is that chromosomal rearrangements occur adjacent to sex-determination loci in different lineages [177], and preferential accumulation of repeats can act to 
drive the emergence of sex chromosomes, such as $\mathrm{Y}$ or $\mathrm{W}$ [178]. Why these repeats are preferentially clustered in sex-linked regions remains unclear. One hypothesis states that amplification of these repeats might promote the suppression of recombination and result in the genetic degradation of $\mathrm{Y}$ or $\mathrm{W}$ and, ultimately, a heteromorphic sex chromosome system might evolve [20,21,36,45,69,177]. Chromosomal changes, including larger inversions and deletions mediated by TE activity, have also been linked to sex chromosome differentiation and evolution [20,179].

\section{Repeats with Sex Chromosomes in Relation to an Ancestral Amniote Super-Sex Chromosome Evolution Hypothesis}

Among amniotes, reptiles are ideal for addressing several fundamental biological questions regarding sex determination systems and sex chromosomes, allowing exploration of evolutionary trajectories for sex chromosome differentiation. Sex determination systems in reptiles are diverse and vary among lineages. All crocodiles exhibit temperature sex determination (TSD), and genomes of turtles that exhibit TSD or genetic sex determination (GSD) are now available [34,100]. Combination of short and long read sequencing can provide chromosome-scale descriptions of repeat landscapes of sex chromosomes using all available genome sequence data from turtles as an ancestral archomorph [155]. Such information will provide insight into the origin and degeneration of sex chromosomes, as well as evidence of conservation of repeats on sex chromosomes across taxa. It could also explain the underlying GSD in amniotes, or whether TSD involves structural modifications in DNA adjacent to, or directly concerned with, the sex-determining genomic regions. The ancient tuatara, all crocodilians, a majority of turtles, and some lizards show TSD $[8,180,181]$, whereas most snakes, many lizards, and some turtles exhibit GSD, and a continuum of differentiation between homomorphic and heteromorphic sex chromosomes within taxa is observed [14,182]. Heteromorphic sex chromosomes show accumulation of satellites and amplification of microsatellites or telomeric repeats on $\mathrm{Y}$ or $\mathrm{W}$ sex chromosomes in many reptilian species and other amniotes [20,45,183-185]. In some reptiles the sex chromosome contains no significant enrichment of repeats [185], whereas minimally differentiated XY chromosomes are observed in three cryptodiran turtles (Staurotypus crassicollis, S. triporcatus, and S. salvinii), in which the $\mathrm{Y}$ chromosomes are smaller than the $\mathrm{X}$ chromosomes owing to a difference in the copy number of 18S-28S rRNA genes [26,118]. One microsatellite amplified on the $\mathrm{W}$ chromosome in several caenophidian snakes is the banded krait minor satellite $(\mathrm{Bkm})$, which consists of a microsatellite repeat motif (AGAT) $)_{n}$ or (GACA) $)_{n}$ sequence, and is associated with the degree of $\mathrm{ZW}$ differentiation [186]. Microsatellites on the $\mathrm{W}$ chromosome of the banded krait snake (Bungarus fasciatus) are also located on the W chromosome of the common tiger snake (Notechis scutatus, Elapidae) [185], and are also observed in Kemp's ridley sea turtle (Lepidochelys kempii) and the green turtle (Chelonia mydas) as TSD species [187] This results from rapid and independent amplification of repeat sequences on $\mathrm{W}$ chromosomes, and suggests that frequent amplification of the repeats has a structural role in heterochromatinization and promotes further sex chromosome differentiation [20]. Similar results have been observed in other amniotes [38], which suggests that amplification of microsatellites has occurred independently in each lineage and might represent convergent sex chromosomal differentiation among amniotes [20,188]. Although sex chromosomes share no homology among amniotes, evidence of linkage homology from several amniotes shows that some overlap of partial sex chromosomal linkage homology is likely to have been part of an ancestral super-sex chromosome [20,21,188,189]. An underlying principle of sex determination in amniote lineages is the sharing of linkage homology, or of sequences such as repeats once linked in a super-sex chromosome that was broken up by different means. Squamate reptile chromosome 2 (SR2) is conserved among squamate reptiles [20,21,186,189], and NORs are generally located on a pair of microchromosomes or chromosome 2 in iguanas and some snakes $[175,190]$. In addition, NORs are located on the ZW microchromosome in bearded dragon (Pogona vitticeps), which shares a common ancestry with SR2 [182,189,191,192]). Two chicken BACs located on Gallus gallus chromosome Z (GGAZ), which show high abundance of LINE and LTR TEs, were mapped on SR2 and the snake W chromosome [20,21]. This finding suggests that 
repeats on the snake $\mathrm{W}$ chromosome also share sex chromosomal linkage homology to SR2 and GGAZ. Such repeats (the telomeric sequence, $(\text { GATA })_{n},(A A G G)_{n}$, and $(A C A G)_{n}$ ) are commonly observed in snake $W$ chromosomes and also in neognathous birds $[20,36,38,78,193,194]$ although the repeats are non-homologous. Similarly, bird and snake W chromosomes share blocks of three repeats (Bkm repeats, 18S-related repeats, and DMRT-related repeats) [185]. These results suggest that repeats are shared partially between the sex chromosomes of chicken and snakes and supports the hypothesis that SR2 and the snake W sex chromosome are associated with a larger ancestral amniote super-sex chromosome (Figure 5) [195-199]. However, the recent chromosome-scale de novo genome assemblies of different vertebrates have not covered this issue, and evidence of chromosome-level genome assemblies is still lacking [200,201]. Although the concept of a super-sex chromosome hypothesis in amniotes has been proposed by a number of cytogenetic based studies evidencing partial linkage homologies, the hypothesis requires improvement for either sex chromosomes of reptiles evolved from a common amniotic ancestral chromosome, or following an independent origin, with a stochastic pattern representing random homologies, where only small sets of genes in a restricted set of species are involved. Convergent evolution of sex chromosomes across distantly related taxa leads to genomic elements, such as repeats, which are particularly adept in a sex-determination role [36]. Are these genes coincidental or are there sequences that serve a selectable function in sex determination in these regions? The hypothesis is not considered as a proven fact and further advanced comparative genomics analysis is recommended. Additional information regarding genomic analysis and transcriptomic activity from squamate reptiles is required to test this hypothesis. Is it possible that amplified microsatellite repeat motifs were retained in the sex chromosomes of a common ancestor, and subsequent reshuffling led to the appearance of sex chromosomes in each lineage?

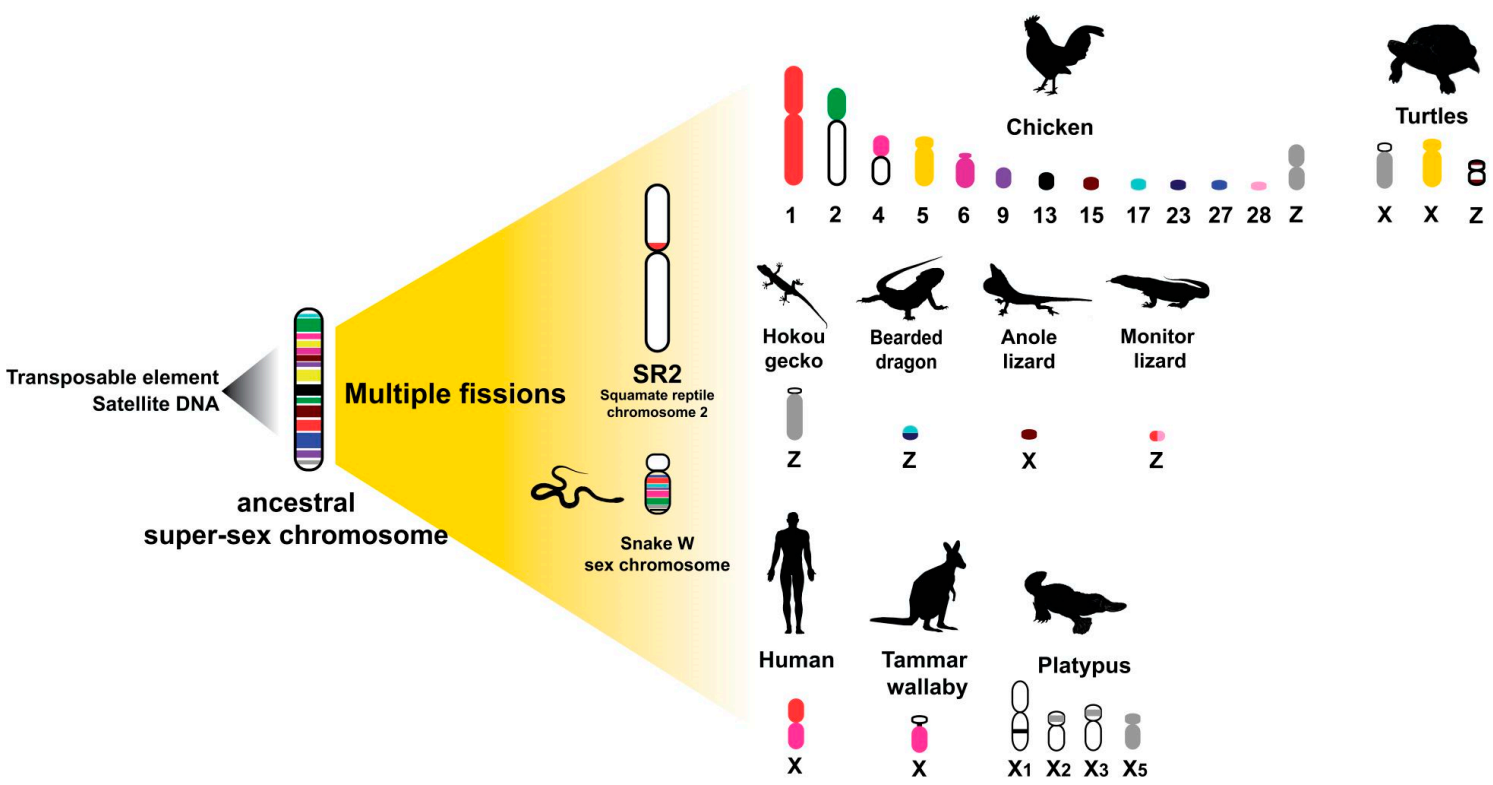

Figure 5. Schematic representation of amniotes sex chromosome evolution. Transposable elements (TEs) mobilization and copy number amplification affected genome reorganization via non-homologous recombination and multiple fission events, resulting in the evolution of heteromorphic $\mathrm{X}$ and $\mathrm{Y}$ or $\mathrm{Z}$ and $\mathrm{W}$ chromosomes in different amniote lineages. Chromosomal locations of genes in the amniotes were obtained from comparative gene mapping (chromosome mapping via a cytogenetic technique) and whole genome sequencing as the following sources: chicken (Gallus gallus) [24], humans (Homo sapiens) and tammar wallaby (Macropus eugenii) [195], duck-billed platypus (Ornithorhynchus anatinus) [196], green anole (Anolis carolinensis) [52], bearded dragon lizard (Pogona vitticeps) [191], Hokou gecko (Gekko hokouensis) [197], 
komodo dragon (Varanus komodoensis) [198], snakes [20,38], marsh turtle (Siebenrockiella crassicollis), wood turtle (Glyptemys insculpta), Mexican musk turtle (Staurotypus triporcatus), giant musk turtle (Staurotypus salvinii), spiny softshell turtle (Apalone spinifera), and Chinese softshell turtle (Pelodiscus sinensis) $[25,26,118,152,199]$.

\section{Evolutionary Products of Micro- and Macrochromosomal Rearrangements in Reptiles}

In addition to the diversity of sex determination systems and sex chromosomes, karyotypes of reptiles constitute a heterogeneous group that is difficult to analyze for chromosome evolution owing to the high degree of variability in chromosome number and composition, even in the absence or presence of microchromosomes [159]. This diversity may help to discover the types and timing of events that contributed to the karyotypes of extant species [200]. On the physical molecular scale, the size of macrochromosomes is generally considered to be greater than $40 \mathrm{Mb}$ and that of microchromosomes less than $20 \mathrm{Mb}$ [196]. It is difficult to trace the evolutionary history of reptile microchromosomes. Microchromosomes were first recorded in iguanid and teiid lizards [202-204]. Microchromosomes are considered to have originated from fragments of ancestral macrochromosomes [205]. Different reptiles possess a varying number and presence or absence of microchromosomes in their chromosomal sets. These karyotypic differences are important in reptile comparative analysis for investigating their genetic makeup and variation [206]. Comparative genomic analyses reveal that genetic linkages were highly conserved between avians and reptilians [15-21,38,52,153,188,189,207,208]. Several crocodile and gecko chromosome pairs are composed of chromosomal segments homologous to turtle and a majority of squamate reptile microchromosomes $[8,15,16,20,21,38,153,207]$. By contrast, the macro- and microchromosomes of turtles are counterparts of those of chicken, which suggests that the ancestral karyotype of Archosauromorpha, probably composed of at least eight pairs of macrochromosomes and many indistinguishable microchromosomes, has been highly conserved for more than 250 million years following their divergence from Lepidosauromorpha $[24,153,209]$. A series of chromosomal fusion-fission events (centric fusion-fission, tandem fusions, insertion, and transposition), followed by centromere inactivation events between macrochromosomes or other microchromosomes, resulted in the diversified karyotypes among squamate reptiles [14-19,38,45,207]. The phylogenetic placement of reptiles and birds in the presence or absence of microchromosomes suggests that the ancestral karyotype of reptiles might have contained both macro- and microchromosomes $[19,52,208]$. The microchromosomes disappeared by fusion between macro- and microchromosomes and/or between microchromosomes in the lineage of crocodiles or gecko in squamate reptiles. Chicken and red-eared slider (Trachemys scripta elegans, $2 n=50$ ) macrochromosomes are remarkably well conserved, considering that these species shared a common ancestor (the Archosauromorpha ancestor) over 200 million years ago [30]. Interestingly, the karyotypic features of the Gila monster, Heloderma suspectum, were described by Pokorná et al. [210] consisting of $2 n=36$ chromosomes (14 macro- and 22 microchromosomes), similar to the Iguania and snake karyotypes [14,211,212]. Microchromosomes might have gained telomeric repeats preferentially. Similar cases are observed in many iguanian lizards and birds $[46,213]$, which suggests that microchromosomes show a higher frequency of recombination than macrochromosomes. In chicken, microchromosomes always show a higher rate of recombination than macrochromosomes [214]. Thus, some regions such as repeats may be functions of the initial copy number and the rate of recombination. Perhaps the rate of recombination might be associated with repeats such as telomeric repeats. However, a genome with a low degree of compartmentalization, which would show limited recombination and a low frequency of chromosomal rearrangements, appears to have been preserved in squamate reptiles, based on the size-specific amplified compartmentalization of satellites, such as microchromosome-specific satellites observed in turtles but not in squamate reptiles [71,166]. Accumulation and conservation of repeats resulted in an increase in chromosome size and number of non-deleterious insertion sites, two features that would have further hampered recombination and chromosomal rearrangements [166]. It would be interesting to determine the crucial impact of chromosomal compartmentalization with species 
diversity for gecko and lacertids and the remaining groups of squamate reptiles with both macroand microchromosomes. Crocodylia, which shows low species richness, rarely exhibits genome rearrangements among members, which suggests that the ancestral crocodilian karyotype was highly conserved with no microchromosomes [8,29]. The rate of chromosomal rearrangements may reduce over evolutionary time until genomic stability and an optimal karyotype is achieved. It is hypothesized that both compositional and structural factors of repeats may drive reptilian karyotypic evolution, with transition from the heterozygous to the homozygous phase through a series of rearrangements. For an improved understanding of the underlying mechanisms, characterization of the specific types of rearrangements, such as cryptic inter- or intrachromosomal changes, and comparative genomic analyses in conjunction with cytogenomics or chromosomics are required to investigate genome structure across diverse reptile lineages [215]. Examination of additional reptilian species is needed to elucidate the mechanisms of microchromosome inheritance during evolution.

\section{Conclusions}

The diversity of genomic structural and sequence composition indicates that the reptilian genome harbors an extreme and divergent landscape of repeats compared with other amniotes. Reptiles may, therefore, represent particularly powerful model systems to evaluate hypotheses concerning genomic structure, function, and evolution. Current data show that contents of total repeats in the genome range from $24.37 \%$ in Coleonyx elegans to $73 \%$ in Coniophanes fissidens. This variation in the genomic proportion of repeats is much higher than that of other amniotes, particularly birds [61]. We hypothesize that genomic and chromosomal variation of reptiles is correlated with a higher rate of repeat-mediated chromosomal rearrangements. In consideration of how the broader range of genomic repeats impacts on chromosomal dynamics and complexity in reptiles, further studies are encouraged to explain the role of repeats in driving evolution and species radiation. Future research is required to identify any novel lineage-specific repeat families among reptilian taxa and clarify the taxonomic distribution of repeats across species within this group. Do these repeats influence the rate of divergence and could repeat-mediated rearrangements play a detrimental role in causing the extinction of a species? How frequently do chromosomal rearrangements occur in different scales and how do rearrangement rates vary between species and lineages? An integrative approach utilizing molecular phylogenetics, cytogenetics, and modern genomics techniques will assist in determining the extent that repeat elements generate and sustain the remarkable diversity of reptiles. In light of the major contribution of reptile genetics to our understanding of amniote evolution, in-depth insights can be gained by integrative genomics (cytogenomics or chromosomics) to fill existing knowledge gaps from classical cytogenetic approaches [215]. With the availability of NGS technologies and robust bioinformatic tools, we are now in a position to combine modern techniques with classical methods to effectively study chromosome-scale rearrangements at a higher resolution. NGS technology has revolutionized the field of chromosomics. Highly reliable chromosome-level genome assemblies present novel opportunities to decipher previously unresolved evolutionary mechanisms. The integration of modern technologies in future research is strongly recommended to explore the causes and consequences of chromosomal rearrangements and gain mechanistic insights into how these processes have reorganized the reptile genome.

Supplementary Materials: The following are available online at http://www.mdpi.com/2073-4425/11/7/827/s1. Figure S1. A comparative bar graph of different repeats percentage in the genome of representative reptile species. Supplementary Dataset S1. List of squamates, birds and mammals species with respective percenatge of TEs. Supplementary Dataset S2.

Author Contributions: S.F.A. and K.S. conceived the review, compiled the relevant literature, and wrote the manuscript. S.F.A., W.S., and T.P. revised the manuscript and assisted with the design of the figures. M.J. revised the manuscript and designed the figures. S.F.A. and M.J. compiled, analyzed, and plotted the repeat contents data of different species. All authors have read and agreed to the published version of the manuscript.

Funding: This review was financially supported by grants from the Center for Advanced Studies in Tropical Natural Resources, National Research University-Kasetsart University (CASTNAR, NRU-KU, Thailand) (no. 
6/2558 and 9/2559) awarded to K.S., the Center for Advanced Studies in Tropical Natural Resources, National Research University-Kasetsart University (CASTNAR, NRU-KU, Thailand) awarded to K.S., the e-ASIA Joint Research Program (no. P1851131) awarded to K.S. and W.S., the National Science and Technology Development Agency (NSTDA) (NSTDA P-19-52238) awarded to K.S. and W.S., a Postdoctoral Researcher award at Kasetsart University awarded to S.F.A. and K.S., the Thailand Research Fund (TRF) (Nos. RSA6180075 and PHD60I0014) through a grant awarded to K.S. and W.S., the Graduate Scholarship Program of the Graduate School, Kasetsart University, Thailand awarded to T.P. and K.S., and the Coordenação de Aperfeiçoamento de Pessoal de Nível Superior Brasil (CAPES: 88882.433287/2019-01) awarded to M.J.

Acknowledgments: We thank the Center for Agricultural Biotechnology (CAB) at the Kasetsart University Kamphaeng Saen Campus for support with server analysis services, and the Faculty of Science and the Faculty of Forestry at Kasetsart University for supporting research facilities. We also thank the National Biobank of Thailand (NBT) under the National Science and Technology Development Agency (NSTDA), Thailand for supporting the high-performance computer.

Conflicts of Interest: The authors declare no conflict of interest.

\section{References}

1. Darwin, C.; Wallace, A. On the Tendency of Species to form Varieties; and on the Perpetuation of Varieties and Species by Natural Means of Selection. J. Proc. Linn. Soc. Lond. Zool. 1858, 3, 45-62. [CrossRef]

2. Darwin, C. The Origin of Species, by Means of Natural Selection, or the Preservation of Favored Races in the Struggle for Life, 2nd ed.; John Murray: London, UK, 1860; pp. 149-150. [CrossRef]

3. Dobzhansky, T. Genetics of Natural Populations. XXVI. Chromosomal Variability in Island and Continental Populations of Drosophila willistoni from Central America and the West Indies. Evolution 1957, 11, 280. [CrossRef]

4. Crombach, A.; Hogeweg, P. Chromosome rearrangements and the evolution of genome structuring and adaptability. Mol. Biol. Evol. 2007, 24, 1130-1139. [CrossRef]

5. Stebbins, G.L. The Inviability, Weakness, and Sterility of Interspecific Hybrids. Adv. Genet. 1958, 9, 147-215. [CrossRef] [PubMed]

6. Harvey, M.G.; Singhal, S.; Rabosky, D.L. Beyond Reproductive Isolation: Demographic Controls on the Speciation Process. Annu. Rev. Ecol. Evol. Syst. 2019, 50, 75-95. [CrossRef]

7. Lynch, M. The Genetic Interpretation of Inbreeding Depression and Outbreeding Depression. Evolution 1991, 45, 622. [CrossRef] [PubMed]

8. Srikulnath, K.; Thapana, W.; Muangmai, N. Role of Chromosome Changes in Crocodylus Evolution and Diversity. Genom. Inform. 2015, 13, 102. [CrossRef] [PubMed]

9. Ponjarat, J.; Singchat, W.; Monkheang, P.; Suntronpong, A.; Tawichasri, P.; Sillapaprayoon, S.; Ogawa, S.; Muangmai, N.; Baicharoen, S.; Peyachoknagul, S.; et al. Evidence of dramatic sterility in F 1 male hybrid catfish [male Clarias gariepinus (Burchell, 1822) $\times$ female C. macrocephalus (Günther, 1864)] resulting from the failure of homologous chromosome pairing in meiosis I. Aquaculture 2019, 505, 84-91. [CrossRef]

10. Donoghue, P.C.J.; Benton, M.J. Rocks and clocks: Calibrating the Tree of Life using fossils and molecules. Trends Ecol. Evol. 2007, 22, 424-431. [CrossRef]

11. Pyron, R.A.; Burbrink, F.T.; Wiens, J.J. A phylogeny and revised classification of Squamata, including 4161 species of lizards and snakes. BMC Evol. Biol. 2013, 13, 1-54. [CrossRef] [PubMed]

12. Srikulnath, K.; Matsubara, K.; Uno, Y.; Thongpan, A.; Suputtitada, S.; Nishida, C.; Matsuda, Y.; Apisitwanich, S. Genetic relationship of three butterfly lizard species (Leiolepis reevesii rubritaeniata, Leiolepis belliana belliana, Leiolepis boehmei, Agamidae, Squamata) inferred from nuclear gene sequence analyses. Kasetsart J. Nat. Sci. 2010, 44, 424-435.

13. Brocklehurst, N.; Kammerer, C.; Frobisch, J. The early evolution of synapsids, and the influence of sampling on their fossil record. Paleobiology 2013, 39, 470-490. [CrossRef]

14. Chromorep: A Reptile Chromosomes Database. Available online: http://chromorep.univpm.it/ (accessed on 13 May 2020).

15. Srikulnath, K.; Matsubara, K.; Uno, Y.; Thongpan, A.; Suputtitada, S.; Apisitwanich, S.; Matsuda, Y.; Nishida, C. Karyological characterization of the butterfly lizard (leiolepis reevesii rubritaeniata, agamidae, squamata) by molecular cytogenetic approach. Cytogenet. Genome Res. 2009, 125, 213-223. [CrossRef] [PubMed] 
16. Srikulnath, K.; Nishida, C.; Matsubara, K.; Uno, Y.; Thongpan, A.; Suputtitada, S.; Apisitwanich, S.; Matsuda, Y. Karyotypic evolution in squamate reptiles: Comparative gene mapping revealed highly conserved linkage homology between the butterfly lizard (Leiolepis reevesii rubritaeniata, Agamidae, Lacertilia) and the Japanese four-striped rat snake (Elaphe quadrivirgata, Colubridae, Serpentes). Chromosome Res. 2009, 17, 975. [CrossRef]

17. Srikulnath, K.; Uno, Y.; Nishida, C.; Matsuda, Y. Karyotype evolution in monitor lizards: Cross-species chromosome mapping of cDNA reveals highly conserved synteny and gene order in the Toxicofera clade. Chromosome Res. 2013, 21, 805-819. [CrossRef] [PubMed]

18. Srikulnath, K.; Matsubara, K.; Uno, Y.; Nishida, C.; Olsson, M.; Matsuda, Y. Identification of the linkage group of the $\mathrm{Z}$ sex chromosomes of the sand lizard (Lacerta agilis, Lacertidae) and elucidation of karyotype evolution in lacertid lizards. Chromosoma 2014, 123, 563-575. [CrossRef] [PubMed]

19. Srikulnath, K.; Uno, Y.; Nishida, C.; Ota, H.; Matsuda, Y. Karyotype reorganization in the Hokou Gecko (Gekko hokouensis, Gekkonidae): The process of microchromosome disappearance in Gekkota. PLoS ONE 2015, 10, e0134829. [CrossRef] [PubMed]

20. Singchat, W.; O'Connor, R.E.; Tawichasri, P.; Suntronpong, A.; Sillapaprayoon, S.; Suntrarachun, S.; Muangmai, N.; Baicharoen, S.; Peyachoknagul, S.; Chanhome, L.; et al. Chromosome map of the Siamese cobra: Did partial synteny of sex chromosomes in the amniote represent "a hypothetical ancestral super-sex chromosome" or random distribution? BMC Genom. 2018, 19, 939. [CrossRef]

21. Singchat, W.; Sillapaprayoon, S.; Muangmai, N.; Baicharoen, S.; Indananda, C.; Duengkae, P.; Peyachoknagul, S.; O'Connor, R.E.; Griffin, D.K.; Srikulnath, K. Do sex chromosomes of snakes, monitor lizards, and iguanian lizards result from multiple fission of an "ancestral amniote super-sex chromosome"? Chromosome Res. 2020, 28, 209-228. [CrossRef]

22. O'Connor, R.E.; Kiazim, L.; Skinner, B.; Fonseka, G.; Joseph, S.; Jennings, R.; Larkin, D.M.; Griffin, D.K. Patterns of microchromosome organization remain highly conserved throughout avian evolution. Chromosoma 2019, 128, 21-29. [CrossRef]

23. Belterman, R.H.R.; De Boer, L.E.M. A karyological study of 55 species of birds, including karyotypes of 39 species new to cytology. Genetica 1984, 65, 39-82. [CrossRef]

24. Matsuda, Y.; Nishida-Umehara, C.; Tarui, H.; Kuroiwa, A.; Yamada, K.; Isobe, T.; Ando, J.; Fujiwara, A.; Hirao, Y.; Nishimura, O.; et al. Highly conserved linkage homology between birds and turtles: Bird and turtle chromosomes are precise counterparts of each other. Chromosome Res. 2005, 13, 601-615. [CrossRef] [PubMed]

25. Kawagoshi, T.; Uno, Y.; Matsubara, K.; Matsuda, Y.; Nishida, C. The ZW micro-sex chromosomes of the chinese soft-shelled turtle (Pelodiscus sinensis, Trionychidae, Testudines) have the same origin as chicken chromosome 15. Cytogenet. Genome Res. 2009, 125, 125-131. [CrossRef] [PubMed]

26. Kawagoshi, T.; Nishida, C.; Matsuda, Y. The origin and differentiation process of $X$ and y chromosomes of the black marsh turtle (Siebenrockiella crassicollis, Geoemydidae, Testudines). Chromosome Res. 2012, 20, 95-110. [CrossRef] [PubMed]

27. Cohen, M.M.; Clark, H.F. The somatic chromosomes of five crocodilian species. Cytogenet. Genome Res. 1967, 6, 193-203. [CrossRef]

28. Kawai, A.; Nishida-Umehara, C.; Ishijima, J.; Tsuda, Y.; Ota, H.; Matsuda, Y. Different origins of bird and reptile sex chromosomes inferred from comparative mapping of chicken Z-linked genes. Cytogenet. Genome Res. 2007, 117, 92-102. [CrossRef]

29. Kawagoshi, T.; Nishida, C.; Ota, H.; Kumazawa, Y.; Endo, H.; Matsuda, Y. Molecular structures of centromeric heterochromatin and karyotypic evolution in the Siamese crocodile (Crocodylus siamensis) (Crocodylidae, Crocodylia). Chromosome Res. 2008, 16, 1119-1132. [CrossRef]

30. Kasai, F.; O’Brien, P.C.M.; Ferguson-Smith, M.A. Reassessment of genome size in turtle and crocodile based on chromosome measurement by flow karyotyping: Close similarity to chicken. Biol. Lett. 2012, 8, 631-635. [CrossRef] [PubMed]

31. Valleley, E.M.A.; Harrison, C.J.; Cook, Y.; Ferguson, M.W.J.; Sharpe, P.T. The karyotype of Alligator mississippiensis, and chromosomal mapping of the ZFY/X homologue, Zff. Chromosoma 1994, 103, 502-507. [CrossRef] [PubMed]

32. Syvänen, A.C. Accessing genetic variation: Genotyping single nucleotide polymorphisms. Nat. Rev. Genet. 2001, 2, 930-942. [CrossRef] [PubMed] 
33. Völker, M.; Backström, N.; Skinner, B.M.; Langley, E.J.; Bunzey, S.K.; Ellegren, H.; Griffin, D.K. Copy number variation, chromosome rearrangement, and their association with recombination during avian evolution. Genome Res. 2010, 20, 503-511. [CrossRef] [PubMed]

34. Bradley, F.H.; Minx, P.; Warren, D.E.; Shedlock, A.M.; Thomson, R.C.; Valenzuela, N.; Abramyan, J.; Amemiya, C.T.; Badenhorst, D.; Biggar, K.K.; et al. The western painted turtle genome, a model for the evolution of extreme physiological adaptations in a slowly evolving lineage. Genome Biol. 2013, 14, 1-23. [CrossRef]

35. Suryamohan, K.; Krishnankutty, S.P.; Guillory, J.; Jevit, M.; Schröder, M.S.; Wu, M.; Kuriakose, B.; Mathew, O.K.; Perumal, R.C.; Koludarov, I.; et al. The Indian cobra reference genome and transcriptome enables comprehensive identification of venom toxins. Nat. Genet. 2020, 52, 106-117. [CrossRef] [PubMed]

36. Thongchum, R.; Singchat, W.; Laopichienpong, N.; Tawichasri, P.; Kraichak, E.; Prakhongcheep, O.; Sillapaprayoon, S.; Muangmai, N.; Baicharoen, S.; Suntrarachun, S.; et al. Diversity of PBI-DdeI satellite DNA in snakes correlates with rapid independent evolution and different functional roles. Sci. Rep. 2019, 9, 1-11. [CrossRef] [PubMed]

37. Kapusta, A.; Suh, A.; Feschotte, C. Dynamics of genome size evolution in birds and mammals. Proc. Natl. Acad. Sci. USA 2017, 114, E1460-E1469. [CrossRef]

38. Matsubara, K.; Tarui, H.; Toriba, M.; Yamada, K.; Nishida-Umehara, C.; Agata, K.; Matsuda, Y. Evidence for different origin of sex chromosomes in snakes, birds, and mammals and step-wise differentiation of snake sex chromosomes. Proc. Natl. Acad. Sci. USA 2006, 103, 18190-18195. [CrossRef]

39. Matsubara, K.; O’Meally, D.; Azad, B.; Georges, A.; Sarre, S.D.; Graves, J.A.M.; Matsuda, Y.; Ezaz, T. Amplification of microsatellite repeat motifs is associated with the evolutionary differentiation and heterochromatinization of sex chromosomes in Sauropsida. Chromosoma 2016, 125, 111-123. [CrossRef]

40. Chaiprasertsri, N.; Uno, Y.; Peyachoknagul, S.; Prakhongcheep, O.; Baicharoen, S.; Charernsuk, S.; Nishida, C.; Matsuda, Y.; Koga, A.; Srikulnath, K. Highly species-specific centromeric repetitive DNA sequences in lizards: Molecular cytogenetic characterization of a novel family of satellite DNA sequences isolated from the water monitor lizard (Varanus salvator macromaculatus, Platynota). J. Hered. 2013, 104, 798-806. [CrossRef]

41. Prakhongcheep, O.; Hirai, Y.; Hara, T.; Srikulnath, K.; Hirai, H.; Koga, A. Two types of Alpha satellite DNA in distinct chromosomal locations in Azara's owl monkey. DNA Res. 2013, 20, 235-240. [CrossRef]

42. Prakhongcheep, O.; Chaiprasertsri, N.; Terada, S.; Hirai, Y.; Srikulnath, K.; Hirai, H.; Koga, A. Heterochromatin blocks constituting the entire short arms of acrocentric chromosomes of Azara's owl monkey: Formation processes inferred from chromosomal locations. DNA Res. 2013, 20, 461-470. [CrossRef]

43. Thapana, W.; Sujiwattanarat, P.; Srikulnath, K.; Hirai, H.; Koga, A. Reduction in the structural instability of cloned eukaryotic tandem-repeat DNA by low-temperature culturing of host bacteria. Genet. Res. 2014, 96. [CrossRef]

44. Sujiwattanarat, P.; Thapana, W.; Srikulnath, K.; Hirai, Y.; Hirai, H.; Koga, A. Higher-order repeat structure in Alpha satellite DNA occurs in New World monkeys and is not confined to hominoids. Sci. Rep. 2015, 5, 10315. [CrossRef]

45. Srikulnath, K.; Azad, B.; Singchat, W.; Ezaz, T. Distribution and amplification of interstitial telomeric sequences (ITSs) in Australian dragon lizards support frequent chromosome fusions in Iguania. PLoS ONE 2019, 14, e0212683. [CrossRef] [PubMed]

46. Suntronpong, A.; Singchat, W.; Kruasuwan, W.; Prakhongcheep, O.; Sillapaprayoon, S.; Muangmai, N.; Somyong, S.; Indananda, C.; Kraichak, E.; Peyachoknagul, S.; et al. Characterization of centromeric satellite DNAs (MALREP) in the Asian swamp eel (Monopterus albus) suggests the possible origin of repeats from transposable elements. Genomics 2020, 112, 3097-3107. [CrossRef]

47. Enukashvily, N.I.; Ponomartsev, N.V. Mammalian satellite DNA: A speaking dumb. Adv. Protein Chem. Struct. Biol. 2013, 9, 31-65.

48. Treangen, T.J.; Salzberg, S.L. Repetitive DNA and next-generation sequencing: Computational challenges and solutions. Nat. Rev. Genet. 2012, 13, 36-46. [CrossRef] [PubMed]

49. Boissinot, S.; Bourgeois, Y.; Manthey, J.D.; Ruggiero, R.P. The mobilome of reptiles: Evolution, structure, and function. Cytogenet. Genome Res. 2019, 157, 21-33. [CrossRef]

50. Lander, E.S.; Linton, L.M.; Birren, B.; Nusbaum, C.; Zody, M.C.; Baldwin, J.; Devon, K.; Dewar, K.; Doyle, M.; Fitzhugh, W.; et al. Initial sequencing and analysis of the human genome. Nature 2001, 409, 860-921. [CrossRef] 
51. Waterston, R.H.; Lindblad-Toh, K.; Birney, E.; Rogers, J.; Abril, J.F.; Agarwal, P.; Agarwala, R.; Ainscough, R.; Alexandersson, M.; An, P.; et al. Initial sequencing and comparative analysis of the mouse genome. Nature 2002, 420, 520-562. [CrossRef]

52. Alföldi, J.; Di Palma, F.; Grabherr, M.; Williams, C.; Kong, L.; Mauceli, E.; Russell, P.; Lowe, C.B.; Glor, R.E.; Jaffe, J.D.; et al. The genome of the green anole lizard and a comparative analysis with birds and mammals. Nature 2011, 477, 587-591. [CrossRef]

53. Tollis, M.; Hutchins, E.D.; Kusumi, K. Reptile genomes open the frontier for comparative analysis of amniote development and regeneration. Int. J. Dev. Biol. 2014, 58, 863-871. [CrossRef] [PubMed]

54. Tollis, M.; Boissinot, S. The evolutionary dynamics of transposable elements in eukaryote genomes. Genome Dyn. 2012, 7, 68-91. [CrossRef] [PubMed]

55. Sotero-Caio, C.G.; Platt, R.N.; Suh, A.; Ray, D.A. Evolution and diversity of transposable elements in vertebrate genomes. Genome Biol. Evol. 2017, 9, 161-177. [CrossRef]

56. Siefert, J.L. Defining the mobilome. Methods Mol. Biol. 2009, 532, 13-27. [PubMed]

57. Warren, I.A.; Naville, M.; Chalopin, D.; Levin, P.; Berger, C.S.; Galiana, D.; Volff, J.N. Evolutionary impact of transposable elements on genomic diversity and lineage-specific innovation in vertebrates. Chromosome Res. 2015, 23, 505-531. [CrossRef]

58. Trizzino, M.; Park, Y.S.; Holsbach-Beltrame, M.; Aracena, K.; Mika, K.; Caliskan, M.; Perry, G.H.; Lynch, V.J.; Brown, C.D. Transposable elements are the primary source of novelty in primate gene regulation. Genome Res. 2017, 27, 1623-1633. [CrossRef] [PubMed]

59. Pasyukova, E.G.; Nuzhdin, S.V.; Morozova, T.V.; Mackay, T.F.C. Accumulation of transposable elements in the genome of Drosophila melanogaster is associated with a decrease in fitness. J. Hered. 2004, 95, 284-290. [CrossRef]

60. Boissinot, S.; Davis, J.; Entezam, A.; Petrov, D.; Furano, A.V. Fitness cost of LINE-1 (L1) activity in humans. Proc. Natl. Acad. Sci. USA 2006, 103, 9590-9594. [CrossRef]

61. Pasquesi, G.I.M.; Adams, R.H.; Card, D.C.; Schield, D.R.; Corbin, A.B.; Perry, B.W.; Reyes-Velasco, J.; Ruggiero, R.P.; Vandewege, M.W.; Shortt, J.A.; et al. Squamate reptiles challenge paradigms of genomic repeat element evolution set by birds and mammals. Nat. Commun. 2018, 9, 1-11. [CrossRef] [PubMed]

62. Suh, A.; Churakov, G.; Ramakodi, M.P.; Platt, R.N.; Jurka, J.; Kojima, K.K.; Caballero, J.; Smit, A.F.; Vliet, K.A.; Hoffmann, F.G.; et al. Multiple lineages of ancient CR1 retroposons shaped the early genome evolution of amniotes. Genome Biol. Evol. 2014, 7, 205-217. [CrossRef]

63. Volff, J.N.; Körting, C.; Schartl, M. Ty3/Gypsy retrotransposon fossils in mammalian genomes: Did they evolve into new cellular functions? Mol. Biol. Evol. 2001, 18, 266-270. [CrossRef]

64. Chalopin, D.; Naville, M.; Plard, F.; Galiana, D.; Volff, J.N. Comparative analysis of transposable elements highlights mobilome diversity and evolution in vertebrates. Genome Biol. Evol. 2015, 7, 567-580. [CrossRef] [PubMed]

65. Valente, G.T.; Mazzuchelli, J.; Ferreira, I.A.; Poletto, A.B.; Fantinatti, B.E.A.; Martins, C. Cytogenetic mapping of the retroelements Rex1, Rex3 and Rex6 among cichlid Fish: New insights on the chromosomal distribution of transposable elements. Cytogenet. Genome Res. 2011, 133, 34-42. [CrossRef] [PubMed]

66. Splendore de Borba, R.; Lourenço da Silva, E.; Parise-Maltempi, P.P. Chromosome mapping of retrotransposable elements Rex 1 and Rex3 in Leporinus Spix, 1829 species (Characiformes: Anostomidae) and its relationships among heterochromatic segments and W sex chromosome. Mob. Genet. Elem. 2013, 3, e27460. [CrossRef]

67. Wichman, H.A.; Van Den Bussche, R.A.; Hamilton, M.J.; Baker, R.J. Transposable elements and the evolution of genome organization in mammals. Genetica 1992, 86, 287-293. [CrossRef] [PubMed]

68. Garrido-Ramos, M.A. Satellite DNA: An evolving topic. Genes 2017, 8, 230. [CrossRef]

69. Matsubara, K.; Uno, Y.; Srikulnath, K.; Seki, R.; Nishida, C.; Matsuda, Y. Molecular cloning and characterization of satellite DNA sequences from constitutive heterochromatin of the habu snake (Protobothrops flavoviridis, Viperidae) and the Burmese python (Python bivittatus, Pythonidae). Chromosoma 2015, 124, 529-539. [CrossRef]

70. Prakhongcheep, O.; Thapana, W.; Suntronpong, A.; Singchat, W.; Pattanatanang, K.; Phatcharakullawarawat, R.; Muangmai, N.; Peyachoknagul, S.; Matsubara, K.; Ezaz, T.; et al. Lack of satellite DNA species-specific homogenization and relationship to chromosomal rearrangements in monitor lizards (Varanidae, Squamata). BMC Evol. Biol. 2017, 17, 193. [CrossRef] 
71. Yamada, K.; Nishida-Umehara, C.; Matsuda, Y. Molecular and cytogenetic characterization of site-specific repetitive DNA sequences in the Chinese soft-shelled turtle (Pelodiscus sinensis, Trionychidae). Chromosome Res. 2005, 13, 33-46. [CrossRef]

72. Dover, G. Molecular drive: A cohesive mode of species evolution. Nature 1982, 299, 111-117. [CrossRef]

73. Dover, G.A. Molecular drive in multigene families: How biological novelties arise, spread and are assimilated. Trends Genet. 1986, 2, 159-165. [CrossRef]

74. Adams, R.H.; Blackmon, H.; Reyes-Velasco, J.; Schield, D.R.; Card, D.C.; Andrew, A.L.; Waynewood, N.; Castoe, T.A. Microsatellite landscape evolutionary dynamics across 450 million years of vertebrate genome evolution. Genome 2016, 59, 295-310. [CrossRef] [PubMed]

75. Neff, B.D.; Gross, M.R. Microsatellite evolution in vertebrates: Inference from AC dinucleotide repeats. Evolution 2001, 55, 1717-1733. [CrossRef] [PubMed]

76. Matsubara, K.; Knopp, T.; Sarre, S.D.; Georges, A.; Ezaz, T. Karyotypic analysis and FISH mapping of microsatellite motifs reveal highly differentiated XX/XY sex chromosomes in the pink-tailed worm-lizard (Aprasia parapulchella, Pygopodidae, Squamata). Mol. Cytogenet. 2013, 6, 1-7. [CrossRef] [PubMed]

77. Rovatsos, M.; Kratochvíl, L.; Altmanová, M.; Pokorná, M.J. Interstitial telomeric motifs in squamate reptiles: When the exceptions outnumber the rule. PLoS ONE 2015, 10, e0134985. [CrossRef] [PubMed]

78. Augstenová, B.; Mazzoleni, S.; Kratochvíl, L.; Rovatsos, M. Evolutionary dynamics of the W chromosome in caenophidian snakes. Genes 2018, 9, 5. [CrossRef]

79. Singh, L.; Purdom, I.F.; Jones, K.W. Sex chromosome associated satellite DNA: Evolution and conservation. Chromosoma 1980, 79, 137-157. [CrossRef]

80. Rovatsos, M.; Altmanová, M.; Johnson Pokorná, M.; Augstenová, B.; Kratochvíl, L. Cytogenetics of the Javan file snake (Acrochordus javanicus) and the evolution of snake sex chromosomes. J. Zool. Syst. Evol. Res. 2018, 56, 117-125. [CrossRef]

81. Mazzoleni, S.; Augstenová, B.; Clemente, L.; Auer, M.; Fritz, U.; Praschag, P.; Protiva, T.; Velenský, P.; Kratochvíl, L.; Rovatsos, M. Sex is determined by XX/XY sex chromosomes in Australasian side-necked turtles (Testudines: Chelidae). Sci. Rep. 2020, 10, 1-11. [CrossRef]

82. Castoe, T.A.; Hall, K.T.; Guibotsy Mboulas, M.L.; Gu, W.; Jason De Koning, A.P.; Fox, S.E.; Poole, A.W.; Vemulapalli, V.; Daza, J.M.; Mockler, T.; et al. Discovery of highly divergent repeat landscapes in snake genomes using high-throughput sequencing. Genome Biol. Evol. 2011, 3, 641-653. [CrossRef]

83. Castoe, T.A.; De Koning, A.P.J.; Hall, K.T.; Card, D.C.; Schield, D.R.; Fujita, M.K.; Ruggiero, R.P.; Degner, J.F.; Daza, J.M.; Gu, W.; et al. The Burmese python genome reveals the molecular basis for extreme adaptation in snakes. Proc. Natl. Acad. Sci. USA 2013, 110, 20645-20650. [CrossRef] [PubMed]

84. Platt, R.N.; Vandewege, M.W.; Ray, D.A. Mammalian transposable elements and their impacts on genome evolution. Chromosome Res. 2018, 26, 25-43. [CrossRef] [PubMed]

85. Zhang, G.; Li, B.; Li, C.; Gilbert, M.T.P.; Jarvis, E.D.; Wang, J. Comparative genomic data of the avian phylogenomics project. Gigascience 2014, 3. [CrossRef]

86. Tollis, M.; Boissinot, S. The transposable element profile of the Anolis genome. Mob. Genet. Elem. 2011, 1, 107-111. [CrossRef] [PubMed]

87. Kordis, D. Transposable elements in reptilian and avian (Sauropsida) genomes. Cytogenet. Genome Res. 2010, 127, 94-111. [CrossRef] [PubMed]

88. Novick, P.A.; Smith, J.D.; Floumanhaft, M.; Ray, D.A.; Stéphane, B. The evolution and diversity of DNA transposons in the genome of the lizard Anolis carolinensis. Genome Biol. Evol. 2011, 3, 1-14. [CrossRef]

89. Piskurek, O.; Nishihara, H.; Okada, N. The evolution of two partner LINE/SINE families and a full-length chromodomain-containing Ty3/Gypsy LTR element in the first reptilian genome of Anolis carolinensis. Gene 2009, 441, 111-118. [CrossRef]

90. Wicker, T.; Sabot, F.; Hua-Van, A.; Bennetzen, J.L.; Capy, P.; Chalhoub, B.; Flavell, A.; Leroy, P.; Morgante, M.; Panaud, O.; et al. A unified classification system for eukaryotic transposable elements. Nat. Rev. Genet. 2007, 8, 973-982. [CrossRef]

91. Yin, W.; Wang, Z.J.; Li, Q.Y.; Lian, J.M.; Zhou, Y.; Lu, B.Z.; Jin, L.J.; Qiu, P.X.; Zhang, P.; Zhu, W.B.; et al. Evolutionary trajectories of snake genes and genomes revealed by comparative analyses of five-pacer viper. Nat. Commun. 2016, 7. [CrossRef] 
92. Green, R.E.; Braun, E.L.; Armstrong, J.; Earl, D.; Nguyen, N.; Hickey, G.; Vandewege, M.W.; St John, J.A.; Capella-Gutiérrez, S.; Castoe, T.A.; et al. Three crocodilian genomes reveal ancestral patterns of evolution among archosaurs. Science 2014, 346. [CrossRef]

93. Rice, E.S.; Kohno, S.; St John, J.; Pham, S.; Howard, J.; Lareau, L.F.; O'Connell, B.L.; Hickey, G.; Armstrong, J.; Deran, A.; et al. Improved genome assembly of American alligator genome reveals conserved architecture of estrogen signaling. Genome Res. 2017, 27, 686-696. [CrossRef] [PubMed]

94. Organ, C.L.; Shedlock, A.M.; Meade, A.; Pagel, M.; Edwards, S.V. Origin of avian genome size and structure in non-avian dinosaurs. Nature 2007, 446, 180-184. [CrossRef] [PubMed]

95. Wan, Q.H.; Pan, S.K.; Hu, L.; Zhu, Y.; Xu, P.W.; Xia, J.Q.; Chen, H.; He, G.Y.; He, J.; Ni, X.W.; et al. Genome analysis and signature discovery for diving and sensory properties of the endangered Chinese alligator. Cell Res. 2013, 23, 1091-1105. [CrossRef] [PubMed]

96. Chong, A.Y.; Kojima, K.K.; Jurka, J.; Ray, D.A.; Smit, A.F.A.; Isberg, S.R.; Gongora, J. Evolution and gene capture in ancient endogenous retroviruses-Insights from the crocodilian genomes. Retrovirology 2014, 11, 71. [CrossRef]

97. Kojima, K.K. A new class of SINEs with snRNA gene-derived heads. Genome Biol. Evol. 2015, 7, $1702-1712$. [CrossRef]

98. Endoh, H.; Okada, N. Total DNA transcription in vitro: A procedure to detect highly repetitive and transcribable sequences with tRNA-like structures. Proc. Natl. Acad. Sci. USA 1986, 83, 251-255. [CrossRef]

99. Kajikawa, M.; Ohshima, K.; Okada, N. Determination of the entire sequence of turtle CR1: The first open reading frame of the turtle CR1 element encodes a protein with a novel zinc finger motif. Mol. Biol. Evol. 1997, 14, 1206-1217. [CrossRef]

100. Wang, Z.; Pascual-Anaya, J.; Zadissa, A.; Li, W.; Niimura, Y.; Huang, Z.; Li, C.; White, S.; Xiong, Z.; Fang, D.; et al. The draft genomes of soft-shell turtle and green sea turtle yield insights into the development and evolution of the turtle-specific body plan. Nat. Genet. 2013, 45, 701-706. [CrossRef]

101. Tollis, M.; DeNardo, D.F.; Cornelius, J.A.; Dolby, G.A.; Edwards, T.; Henen, B.T.; Karl, A.E.; Murphy, R.W.; Kusumi, K. The Agassiz's desert tortoise genome provides a resource for the conservation of a threatened species. PLoS ONE 2017, 12, e0177708. [CrossRef]

102. Giovannotti, M.; Nisi Cerioni, P.; Caputo, V.; Olmo, E. Characterisation of a GC-rich telomeric satellite DNA in Eumeces schneideri Daudin (Reptilia, Scincidae). Cytogenet. Genome Res. 2009, 125, 272-278. [CrossRef]

103. Capriglione, T.; Cardone, A.; Odierna, G.; Olmo, E. Evolution of a centromeric satellite DNA and phylogeny of lacertid lizards. Comp. Biochem. Physiol. Part B Biochem. 1991, 100, 641-645. [CrossRef]

104. Capriglione, T.; Cardone, A.; Odierna, G.; Olmo, E. Further data on the occurrence and evolution of satellite DNA families in the lacertid genome. Chromosome Res. 1994, 2, 327-330. [CrossRef] [PubMed]

105. Capriglione, T.; De Santo, M.G.; Odierna, G.; Olmo, E. An alphoid-like satellite DNA sequence is present in the genome of a lacertid lizard. J. Mol. Evol. 1998, 46, 240-244. [CrossRef]

106. Ciobanu, D.; Grechko, V.V.; Darevsky, I.S.; Kramerov, D.A. New satellite DNA in Lacerta s. str. lizards (Sauria: Lacertidae): Evolutionary pathways and phylogenetic impact. J. Exp. Zool. Part B Mol. Dev. Evol. 2004, 302, 505-516. [CrossRef] [PubMed]

107. Grechko, V.V.; Ciobanu, D.G.; Darevsky, I.S.; Kramerov, D.A. Satellite DNA of lizards of the genus Lacerta s. str. (the group L. agilis), the family Lacertidae. Dokl. Biochem. Biophys. 2005, 400, 44-47. [CrossRef] [PubMed]

108. Giovannotti, M.; Cerioni, P.N.; Splendiani, A.; Ruggeri, P.; Olmo, E.; Barucchi, V.C. Slow evolving satellite DNAs: The case of a centromeric satellite in Chalcides ocellatus (Forskål, 1775) (Reptilia, Scincidae). Amphib. Reptil. 2014, 34, 401-411. [CrossRef]

109. Giovannotti, M.; Nisi Cerioni, P.; Rojo, V.; Olmo, E.; Slimani, T.; Splendiani, A.; Caputo Barucchi, V. Characterization of a satellite DNA in the genera Lacerta and Timon (Reptilia, Lacertidae) and its role in the differentiation of the W chromosome. J. Exp. Zool. Part B Mol. Dev. Evol. 2018, 330, 83-95. [CrossRef]

110. Giovannotti, M.; S’Khifa, A.; Nisi Cerioni, P.; Splendiani, A.; Slimani, T.; Fioravanti, T.; Olmo, E.; Caputo Barucchi, V. Isolation and characterization of two satellite DNAs in Atlantolacerta andreanskyi (Werner, 1929) (Reptilia, Lacertidae). J. Exp. Zool. Part B Mol. Dev. Evol. 2020, 334, 178-191. [CrossRef] [PubMed]

111. Rojo, V.; Martínez-Lage, A.; Giovannotti, M.; González-Tizón, A.M.; Cerioni, P.N.; Barucchi, V.C.; Galán, P.; Olmo, E.; Naveira, H. Evolutionary dynamics of two satellite DNA families in rock lizards of the genus Iberolacerta (Squamata, Lacertidae): Different histories but common traits. Chromosome Res. 2015, 23, 441-461. [CrossRef] [PubMed] 
112. Ciobanu, D.G.; Grechko, V.V.; Kramerov, D.A.; Darevsky, I.S. A new subfamily of the satellite DNA, CLsatIV, of the lizard Darevskia lindholmi (Sauria, Laceridae): Structure and evolution. Dokl. Biochem. Biophys. 2003, 392, 263-267. [CrossRef]

113. Ciobanu, D.G.; Grechko, V.V.; Darevsky, I.S. Molecular evolution of satellite DNA CLsat in lizards from the genus Dareuskia (Sauria: Lacertidae): Correlation with species diversity. Russ. J. Genet. 2003, 39, 1292-1305. [CrossRef]

114. Grechko, V.V.; Ciobanu, D.G.; Darevsky, I.S.; Kosushkin, S.A.; Kramerov, D.A. Molecular evolution of satellite DNA repeats and speciation of lizards of the genus Darevskia (Sauria: Lacertidae). Genome 2006, 49, 1297-1307. [CrossRef] [PubMed]

115. Capriglione, T.; Olmo, E.; Odierna, G.; Smith, D.I.; Miller, O.J. Genome composition and tandemly repetitive sequence at some centromeres in the lizard Podarcis s. sicula Raf. Genetica 1989, 79, 85-91. [CrossRef]

116. Gatesy, J.; Amato, G.; Norell, M.; DeSalle, R.; Hayashi, C. Combined support for wholesale taxic atavism in gavialine crocodylians. Syst. Biol. 2003, 52, 403-422. [CrossRef]

117. Harshman, J.; Huddleston, C.J.; Bollback, J.P.; Parsons, T.J.; Braun, M.J. True and false gharials: A nuclear gene phylogeny of Crocodylia. Syst. Biol. 2003, 52, 386-402. [CrossRef]

118. Kawagoshi, T.; Uno, Y.; Nishida, C.; Matsuda, Y. The Staurotypus turtles and aves share the same origin of sex chromosomes but evolved different types of heterogametic sex determination. PLoS ONE 2014, 9, e105315. [CrossRef]

119. Badenhorst, D.; Hillier, L.D.W.; Literman, R.; Montiel, E.E.; Radhakrishnan, S.; Shen, Y.; Minx, P.; Janes, D.E.; Warren, W.C.; Edwards, S.V.; et al. Physical mapping and refinement of the painted turtle genome (chrysemys picta) inform amniote genome evolution and challenge turtle-bird chromosomal conservation. Genome Biol. Evol. 2015, 7, 2038-2050. [CrossRef]

120. Klein, S.J.; O’Neill, R.J. Transposable elements: Genome innovation, chromosome diversity, and centromere conflict. Chromosome Res. 2018, 26, 5-23. [CrossRef]

121. Kazazian, H.H. Mobile Elements: Drivers of Genome Evolution. Science 2004, 303, 1626-1632. [CrossRef]

122. Pritham, E.J.; Feschotte, C. Massive amplification of rolling-circle transposons in the lineage of the bat Myotis lucifugus. Proc. Natl. Acad. Sci. USA 2007, 104, 1895-1900. [CrossRef]

123. Böhne, A.; Brunet, F.; Galiana-Arnoux, D.; Schultheis, C.; Volff, J.N. Transposable elements as drivers of genomic and biological diversity in vertebrates. Chromosome Res. 2008, 16, 203-215. [CrossRef] [PubMed]

124. Stebbins, G.L. Chromosomal variation and evolution. Science 1966, 152, 1463-14693. [CrossRef] [PubMed]

125. Ålund, M. Gametes and Speciation: From Prezygotic to Postzygotic Isolation; Department of Animal Ecology, Evolutionary Biology Centre, Uppsala University: Uppsala, Sweden, 2012; Volume 100.

126. Islam, F.B.; Ishishita, S.; Uno, Y.; Mollah, M.B.R.; Srikulnath, K.; Matsuda, Y. Male hybrid sterility in the mule duck is associated with meiotic arrest in primary spermatocytes. Poult. Sci. J. 2013, 50, 311-320. [CrossRef]

127. Hurst, G.D.D.; Schilthuizen, M. Selfish genetic elements and speciation. Heredity (Edinburgh) 1998, 80, 2-8. [CrossRef]

128. Jurka, J.; Bao, W.; Kojima, K.K. Families of transposable elements, population structure and the origin of species. Biol. Direct 2011, 6, 44. [CrossRef] [PubMed]

129. Belyayev, A. Bursts of transposable elements as an evolutionary driving force. J. Evol. Biol. 2014, 27, 2573-2584. [CrossRef]

130. Serrato-Capuchina, A.; Matute, D.R. The role of transposable elements in speciation. Genes (Basel) 2018, 9, 254. [CrossRef]

131. Verneau, O.; Catzeflis, F.; Furano, A.V. Determining and dating recent rodent speciation events by using L1 (LINE-1) retrotransposons. Proc. Natl. Acad. Sci. USA 1998, 95, 11284-11289. [CrossRef] [PubMed]

132. Dobigny, G.; Ozouf-Costaz, C.; Waters, P.D.; Bonillo, C.; Coutanceau, J.P.; Volobouev, V. LINE-1 amplification accompanies explosive genome repatterning in rodents. Chromosome Res. 2004, 12, 787-793. [CrossRef]

133. Ray, D.A.; Feschotte, C.; Pagan, H.J.T.; Smith, J.D.; Pritham, E.J.; Arensburger, P.; Atkinson, P.W.; Craig, N.L. Multiple waves of recent DNA transposon activity in the bat, Myotis lucifugus. Genome Res. 2008, 18, 717-728. [CrossRef] [PubMed]

134. De Boer, J.G.; Yazawa, R.; Davidson, W.S.; Koop, B.F. Bursts and horizontal evolution of DNA transposons in the speciation of pseudotetraploid salmonids. BMC Genom. 2007, 8, 422. [CrossRef] [PubMed]

135. Gilbert, C.; Hernandez, S.S.; Flores-Benabib, J.; Smith, E.N.; Feschotte, C. Rampant horizontal transfer of SPIN transposons in squamate reptiles. Mol. Biol. Evol. 2012, 29, 503-515. [CrossRef] [PubMed] 
136. Kraaijeveld, K. Genome Size and Species Diversification. Evol. Biol. 2010, 37, 227-233. [CrossRef] [PubMed]

137. Plohl, M.; Meštrović, N.; Mravinac, B. Satellite DNA evolution. Genome Dyn. 2012, 7, 126-152. [CrossRef] [PubMed]

138. Bachmann, L.; Raab, M.; Sperlich, D. Satellite DNA and speciation: A species specific satellite DNA of Drosophila guanche. J. Zool. Syst. Evol. Res. 1989, 27, 84-93. [CrossRef]

139. Lower, S.S.; McGurk, M.P.; Clark, A.G.; Barbash, D.A. Satellite DNA evolution: Old ideas, new approaches. Curr. Opin. Genet. Dev. 2018, 49, 70-78. [CrossRef]

140. Adega, F.; Guedes-Pinto, H.; Chaves, R. Satellite DNA in the karyotype evolution of domestic animals-Clinical considerations. Cytogenet. Genome Res. 2009, 126, 12-20. [CrossRef]

141. Ruiz-Herrera, A.; Castresana, J.; Robinson, T.J. Is mammalian chromosomal evolution driven by regions of genome fragility? Genome Biol. 2006, 7. [CrossRef]

142. Farré, M.; Bosch, M.; López-Giráldez, F.; Ponsà, M.; Ruiz-Herrera, A. Assessing the role of tandem repeats in shaping the genomic architecture of great apes. PLOS ONE 2011, 6. [CrossRef]

143. Vieira-Da-Silva, A.; Louzada, S.; Adega, F.; Chaves, R. A high-resolution comparative chromosome map of Cricetus cricetus and Peromyscus eremicus reveals the involvement of constitutive heterochromatin in breakpoint regions. Cytogenet. Genome Res. 2015, 145, 59-67. [CrossRef]

144. De La Fuente, R.; Baumann, C.; Viveiros, M.M. ATRX contributes to epigenetic asymmetry and silencing of major satellite transcripts in the maternal genome of the mouse embryo. Development 2015, 142, 1806-1817. [CrossRef]

145. Giunta, S.; Funabiki, H. Integrity of the human centromere DNA repeats is protected by CENP-A, CENP-C, and CENP-T. Proc. Natl. Acad. Sci. USA 2017, 114, 1928-1933. [CrossRef]

146. Srikulnath, K.; Uno, Y.; Matsubara, K.; Thongpan, A.; Suputtitada, S.; Apisitwanich, S.; Nishida, C.; Matsuda, Y. Chromosomal localization of the 18S-28S and 5s rRNA genes and (TTAGGG)n sequences of butterfly lizards (Leiolepis belliana belliana and Leiolepis boehmei, Agamidae, Squamata). Genet. Mol. Biol. 2011, 34, 582-586. [CrossRef] [PubMed]

147. Louzada, S.; Lopes, M.; Ferreira, D.; Adega, F.; Escudeiro, A.; Gama-carvalho, M.; Chaves, R. Decoding the role of satellite DNA in genome architecture and plasticity-An evolutionary and clinical affair. Genes (Basel) 2020, 11, 72. [CrossRef] [PubMed]

148. Feliciello, I.; Akrap, I.; Brajkovi, J.; Zlatar, I.; Ugarkovic, D. Satellite DNA as a driver of population divergence in the red flour beetle tribolium castaneum. Genome Biol. Evol. 2014, 7, 228-239. [CrossRef] [PubMed]

149. Farré, M.; Robinson, T.J.; Ruiz-Herrera, A. An integrative breakage model of genome architecture, reshuffling and evolution: The integrative breakage model of genome evolution, a novel multidisciplinary hypothesis for the study of genome plasticity. BioEssays 2015, 37, 479-488. [CrossRef] [PubMed]

150. Chaves, R.; Louzada, S.; Meles, S.; Wienberg, J.; Adega, F. Praomys tullbergi (Muridae, Rodentia) genome architecture decoded by comparative chromosome painting with Mus and Rattus. Chromosome Res. 2012, 20, 673-683. [CrossRef]

151. Farré, M.; Narayan, J.; Slavov, G.T.; Damas, J.; Auvil, L.; Li, C.; Jarvis, E.D.; Burt, D.W.; Griffin, D.K.; Larkin, D.M. Novel insights into chromosome evolution in birds, archosaurs, and reptiles. Genome Biol. Evol. 2016, 8, 2442-2451. [CrossRef]

152. Badenhorst, D.; Stanyon, R.; Engstrom, T.; Valenzuela, N. A ZZ/ZW microchromosome system in the spiny softshell turtle, Apalone spinifera, reveals an intriguing sex chromosome conservation in Trionychidae. Chromosome Res. 2013, 21, 137-147. [CrossRef]

153. Uno, Y.; Nishida, C.; Tarui, H.; Ishishita, S.; Takagi, C.; Nishimura, O.; Ishijima, J.; Ota, H.; Kosaka, A.; Matsubara, K.; et al. Inference of the protokaryotypes of amniotes and tetrapods and the evolutionary processes of microchromosomes from comparative gene mapping. PLoS ONE 2012, 7, e0053027. [CrossRef]

154. Giovannotti, M.; Caputo, V.; O’Brien, P.C.M.; Lovell, F.L.; Trifonov, V.; Nisi Cerioni, P.; Olmo, E.; Ferguson-Smith, M.A.; Rens, W. Skinks (reptilia: Scincidae) have highly conserved karyotypes as revealed by chromosome painting. Cytogenet. Genome Res. 2010, 127, 224-231. [CrossRef]

155. Janes, D.E.; Organ, C.L.; Fujita, M.K.; Shedlock, A.M.; Edwards, S.V. genome evolution in reptilia, the sister group of mammals. Annu. Rev. Genom. Hum. Genet. 2010, 11, 239-264. [CrossRef]

156. Trifonov, V.A.; Paoletti, A.; Caputo Barucchi, V.; Kalinina, T.; O’Brien, P.C.M.; Ferguson-Smith, M.A.; Giovannotti, M. Comparative chromosome painting and NOR distribution suggest a complex hybrid origin of triploid Lepidodactylus lugubris (Gekkonidae). PLoS ONE 2015, 10, e0132380. [CrossRef] [PubMed] 
157. Damas, J.; O'Connor, R.; Farré, M.; Lenis, V.P.E.; Martell, H.J.; Mandawala, A.; Fowler, K.; Joseph, S.; Swain, M.T.; Griffin, D.K.; et al. Upgrading short-read animal genome assemblies to chromosome level using comparative genomics and a universal probe set. Genome Res. 2017. [CrossRef]

158. O'Connor, R.E.; Romanov, M.N.; Kiazim, L.G.; Barrett, P.M.; Farré, M.; Damas, J.; Ferguson-Smith, M.; Valenzuela, N.; Larkin, D.M.; Griffin, D.K. Reconstruction of the diapsid ancestral genome permits chromosome evolution tracing in avian and non-avian dinosaurs. Nat. Commun. 2018. [CrossRef] [PubMed]

159. Olmo, E. Trends in the evolution of reptilian chromosomes. Integr. Comp. Biol. 2008, 48, 486-493. [CrossRef] [PubMed]

160. Yamagishi, M.; Matsubara, K.; Sakaizumi, M. Molecular cytogenetic identification and characterization of Robertsonian chromosomes in the large Japanese field mouse (Apodemus speciosus) using FISH. Zoolog. Sci. 2012, 29, 709-713. [CrossRef]

161. Lönnig, W.-E.; Saedler, H. Chromosome Rearrangements and Transposable Elements. Annu. Rev. Genet. 2002, 36, 389-410. [CrossRef]

162. Rocchi, M.; Archidiacono, N.; Schempp, W.; Capozzi, O.; Stanyon, R. Centromere repositioning in mammals. Heredity (Edinburgh) 2012, 108, 59-67. [CrossRef]

163. Sankoff, D. The where and wherefore of evolutionary breakpoints. J. Biol. 2009, 8, 66. [CrossRef]

164. Longo, M.S.; Carone, D.M.; Green, E.D.; O’Neill, M.J.; O’Neill, R.J. Distinct retroelement classes define evolutionary breakpoints demarcating sites of evolutionary novelty. BMC Genom. 2009, 10. [CrossRef]

165. Coghlan, A.; Eichler, E.E.; Oliver, S.G.; Paterson, A.H.; Stein, L. Chromosome evolution in eukaryotes: A multi-kingdom perspective. Trends Genet. 2005, 21, 673-682. [CrossRef]

166. Olmo, E. Rate of chromosome changes and speciation in reptiles. Genetica 2005, 125, 185-203. [CrossRef] [PubMed]

167. Hall, W.P. Chromosome variation, genomics, speciation and evolution in sceloporus lizards. Cytogenet. Genome Res. 2010, 127, 143-165. [CrossRef]

168. Lu, W.; Zhang, Y.; Liu, D.; Songyang, Z.; Wan, M. Telomeres-structure, function, and regulation. Exp. Cell Res. 2013, 319, 133-141. [CrossRef]

169. Singchat, W.; Kraichak, E.; Tawichasri, P.; Tawan, T.; Suntronpong, A.; Sillapaprayoon, S.; Phatcharakullawarawat, R.; Muangmai, N.; Suntrarachun, S.; Baicharoen, S.; et al. Dynamics of telomere length in captive Siamese cobra (Naja kaouthia) related to age and sex. Ecol. Evol. 2019, 9, 6366-6377. [CrossRef]

170. Bolzán, A.D.; Bianchi, M.S. Telomeres, interstitial telomeric repeat sequences, and chromosomal aberrations. Mutat. Res. Rev. Mutat. Res. 2006, 612, 189-214. [CrossRef] [PubMed]

171. Ruiz-Herrera, A.; Nergadze, S.G.; Santagostino, M.; Giulotto, E. Telomeric repeats far from the ends: Mechanisms of origin and role in evolution. Cytogenet. Genome Res. 2009, 122, 219-228. [CrossRef] [PubMed]

172. Slijepcevic, P.; Xiao, Y.; Dominguez, I.; Natarajan, A.T. Spontaneous and radiation-induced chromosomal breakage at interstitial telomeric sites. Chromosoma 1996, 104, 596-604. [CrossRef]

173. Slijepcevic, P. Telomeres and mechanisms of Robertsonian fusion. Chromosoma 1998, 107, 136-140. [CrossRef]

174. Lee, B.; Sasi, R.; Lin, C.C. Interstitial localization of telomeric dima sequences in the indian muntjac chromosomes: Further evidence for tandem chromosome fusions in the karyotypic evolution of the asian muntjacs. Cytogenet. Genome Res. 1993, 63, 156-159. [CrossRef] [PubMed]

175. Pellegrino, K.C.M.; Bertolotto, C.E.V.; Yonenaga-Yassuda, Y.; Rodrigues, M.T. Banding patterns, heteromorphic sex chromosomes and Agstained NORs after pachytene stage in the meiosis of the Brazilian lizard Urostrophus vautieri (Squamata, Polychrotidae). Caryologia 1999, 52, 21-26. [CrossRef]

176. Nergadze, S.G.; Rocchi, M.; Azzalin, C.M.; Mondello, C.; Giulotto, E. Insertion of telomeric repeats at intrachromosomal break sites during primate evolution. Genome Res. 2004, 14, 1704-1710. [CrossRef]

177. Ezaz, T.; Deakin, J.E. Repetitive sequence and sex chromosome evolution in vertebrates. Adv. Evol. Biol. 2014, 2014, 1-9. [CrossRef]

178. Deakin, J.E.; Ezaz, T. Tracing the evolution of amniote chromosomes. Chromosoma 2014, 123, $201-216$. [CrossRef]

179. Steinemann, S.; Steinemann, M. Retroelements: Tools for sex chromosome evolution. Cytogenet. Genome Res. 2005, 110, 134-143. [CrossRef] [PubMed] 
180. Ezaz, T.; Stiglec, R.; Veyrunes, F.; Marshall Graves, J.A. Relationships between Vertebrate ZW and XY Sex Chromosome Systems. Curr. Biol. 2006, 16, R736-R743. [CrossRef] [PubMed]

181. Janzen, F.J.; Phillips, P.C. Exploring the evolution of environmental sex determination, especially in reptiles. J. Evol. Biol. 2006, 19, 1775-1784. [CrossRef] [PubMed]

182. Ezaz, T.; Quinn, A.E.; Sarre, S.D.; O’Meally, D.; Georges, A.; Marshall Graves, J.A. Molecular marker suggests rapid changes of sex-determining mechanisms in Australian dragon lizards. Chromosom. Res. 2009, 17, 91-98. [CrossRef]

183. Matsubara, K.; Uno, Y.; Srikulnath, K.; Matsuda, Y.; Miller, E.; Olsson, M. No interstitial telomeres on autosomes but remarkable amplification of telomeric repeats on the $\mathrm{W}$ sex chromosome in the sand lizard (Lacerta agilis). J. Hered. 2015, 106, 753-757. [CrossRef]

184. O'Neill, M.J.; O'Neill, R.J. Sex chromosome repeats tip the balance towards speciation. Mol. Ecol. 2018, 27, 3783-3798. [CrossRef] [PubMed]

185. O'Meally, D.; Patel, H.R.; Stiglec, R.; Sarre, S.D.; Georges, A.; Marshall Graves, J.A.; Ezaz, T. Non-homologous sex chromosomes of birds and snakes share repetitive sequences. Chromosom. Res. 2010, 18, 787-800. [CrossRef]

186. Subramanian, S.; Mishra, R.K.; Singh, L. Genome-wide analysis of Bkm sequences (GATA repeats): Predominant association with sex chromosomes and potential role in higher order chromatin organization and function. Bioinformatics 2003, 19, 681-685. [CrossRef]

187. Demas, S.; Duronslet, M.; Wachtel, S.; Caillouet, C.; Nakamura, D. Sex-specific DNA in reptiles with temperature sex determination. J. Exp. Zool. 1990, 253, 319-324. [CrossRef]

188. Ezaz, T.; Srikulnath, K.; Graves, J.A.M. Origin of amniote sex chromosomes: An ancestral super-sex chromosome, or common requirements? J. Hered. 2017, 108, 94-105. [CrossRef]

189. Matsubara, K.; O’Meally, D.; Sarre, S.D.; Georges, A.; Srikulnath, K.; Ezaz, T. ZW sex chromosomes in Australian dragon lizards (Agamidae) originated from a combination of duplication and translocation in the nucleolar organising region. Genes (Basel) 2019, 10. [CrossRef] [PubMed]

190. Porter, C.A.; Haiduk, M.W.; de Queiroz, K. Evolution and phylogenetic significance of ribosomal gene location in chromosomes of squamate reptiles. Copeia 1994, 1994, 302. [CrossRef]

191. Ezaz, T.; Azad, B.; O’Meally, D.; Young, M.J.; Matsubara, K.; Edwards, M.J.; Zhang, X.; Holleley, C.E.; Deakin, J.E.; Marshall Graves, J.A.; et al. Sequence and gene content of a large fragment of a lizard sex chromosome and evaluation of candidate sex differentiating gene R-spondin 1. BMC Genom. 2013, 14. [CrossRef] [PubMed]

192. Young, M.J.; O'Meally, D.; Sarre, S.D.; Georges, A.; Ezaz, T. Molecular cytogenetic map of the central bearded dragon, Pogona vitticeps (Squamata: Agamidae). Chromosome Res. 2013, 21, 361-374. [CrossRef]

193. Vicoso, B.; Emerson, J.J.; Zektser, Y.; Mahajan, S.; Bachtrog, D. Comparative sex chromosome genomics in snakes: Differentiation, evolutionary strata, and lack of global dosage compensation. PLoS Biol. 2013, 11, e1001643. [CrossRef]

194. Matsubara, K.; Sarre, S.D.; Georges, A.; Matsuda, Y.; Marshall Graves, J.A.; Ezaz, T. Highly differentiated ZW sex microchromosomes in the Australian Varanus species evolved through rapid amplification of repetitive sequences. PLoS ONE 2014, 9, e95226. [CrossRef] [PubMed]

195. Grützner, F.; Rens, W.; Tsend-Ayush, E.; El-Mogharbel, N.; O’Brien, P.C.; Jones, R.C.; Ferguson-Smith, M.A.; Graves, J.A.M. In the platypus a meiotic chain of ten sex chromosomes shares genes with the bird $\mathrm{Z}$ and mammal X chromosomes. Nature 2004, 432, 913-917. [CrossRef] [PubMed]

196. Veyrunes, F.; Waters, P.D.; Miethke, P.; Rens, W.; McMillan, D.; Alsop, A.E.; Grützner, F.; Deakin, J.E.; Whittington, C.M.; Schatzkamer, K.; et al. Bird-like sex chromosomes of platypus imply recent origin of mammal sex chromosomes. Genome Res. 2008, 18, 965-973. [CrossRef] [PubMed]

197. Kawai, A.; Ishijima, J.; Nishida, C.; Kosaka, A.; Ota, H.; Kohno, S.; Matsuda, Y. The ZW sex chromosomes of Gekko hokouensis (Gekkonidae, Squamata) represent highly conserved homology with those of avian species. Chromosoma 2009, 118, 43-51. [CrossRef] [PubMed]

198. Lind, A.L.; Lai, Y.; Mostovoy, Y.; Holloway, A.K.; Iannucci, A.; Mak, A.; Fondi, M.; Orlandini, V.; Eckalbar, W.L.; Milan, M.; et al. Genome of the Komodo dragon reveals adaptations in the cardiovascular and chemosensory systems of monitor lizards. Nat. Ecol. Evol. 2019, 3, 1241-1252. [CrossRef] [PubMed] 
199. Montiel, E.E.; Badenhorst, D.; Tamplin, J.; Burke, R.L.; Valenzuela, N. Discovery of the youngest sex chromosomes reveals first case of convergent co-option of ancestral autosomes in turtles. Chromosoma 2016, 126, 105-113. [CrossRef]

200. Braasch, I.; Gehrke, A.R.; Smith, J.J.; Kawasaki, K.; Manousaki, T.; Pasquier, J.; Amores, A.; Desvignes, T.; Batzel, P.; Catchen, J.; et al. The spotted gar genome illuminates vertebrate evolution and facilitates human-teleost comparisons. Nat. Genet. 2016, 48, 427-437. [CrossRef]

201. Simakov, O.; Marlétaz, F.; Yue, J.X.; O'Connell, B.; Jenkins, J.; Brandt, A.; Calef, R.; Tung, C.H.; Huang, T.K.; Schmutz, J.; et al. Deeply conserved synteny resolves early events in vertebrate evolution. Nat. Ecol. Evol. 2020, 4, 1-11. [CrossRef]

202. Deakin, J.E.; Ezaz, T. Understanding the evolution of reptile chromosomes through applications of combined cytogenetics and genomics approaches. Cytogenet. Genome Res. 2019, 157, 7-20. [CrossRef] [PubMed]

203. Axelsson, E.; Webster, M.T.; Smith, N.G.C.; Burt, D.W.; Ellegren, H. Comparison of the chicken and turkey genomes reveals a higher rate of nucleotide divergence on microchromosomes than macrochromosomes. Genome Res. 2005, 15, 120-125. [CrossRef] [PubMed]

204. Painter, T.S. The Y-chromosome in mammals. Science 1921, 53, 503-504. [CrossRef]

205. Matthey, R.; Bovey, R. The chromosomal formula in five species of Chiroptera. Experientia 1948, 4, $26-27$.

206. Peccinini, D.; Frota-Pessoa, O.; Ferrari, I. Sex determination of the "pseudo-xo/xx" type in the brazilian lizard polychrus sp. (sauria, iguanidae). Caryologia 1971, 24, 129-139. [CrossRef]

207. Fillon, V.; Morisson, M.; Zoorob, R.; Auffray, C.; Douaire, M.; Gellin, J.; Vignal, A. Identification of 16 chicken microchromosomes by molecular markers using two-colour fluorescence in situ hybridization (FISH). Chromosome Res. 1998, 6, 307-313. [CrossRef] [PubMed]

208. Solinhac, R.; Leroux, S.; Galkina, S.; Chazara, O.; Feve, K.; Vignoles, F.; Morisson, M.; Derjusheva, S.; Bed'hom, B.; Vignal, A.; et al. Integrative mapping analysis of chicken microchromosome 16 organization. BMC Genom. 2010, 11, 1-12. [CrossRef] [PubMed]

209. Matsubara, K.; Kuraku, S.; Tarui, H.; Nishimura, O.; Nishida, C.; Agata, K.; Kumazawa, Y.; Matsuda, Y. Intra-genomic GC heterogeneity in sauropsids: Evolutionary insights from cDNA mapping and GC3 profiling in snake. BMC Genom. 2012, 13, 1-14. [CrossRef]

210. Pokorná, M.; Kratochvíl, L.; Kejnovský, E. Microsatellite distribution on sex chromosomes at different stages of heteromorphism and heterochromatinization in two lizard species (Squamata: Eublepharidae: Coleonyx elegans and Lacertidae: Eremias velox). BMC Genet. 2011, 12. [CrossRef] [PubMed]

211. Shedlock, A.M.; Edwards, S. V Amniotes (Amniota). In The Timetree of Life; Oxford University Press: New York, NY, USA, 2009.

212. Pokorná, M.; Altmanová, M.; Kratochvíl, L. Multiple sex chromosomes in the light of female meiotic drive in amniote vertebrates. Chromosome Res. 2014, 22, 35-44. [CrossRef] [PubMed]

213. Singh, L. Evolution of karyotypes in snakes. Chromosoma 1972, 38, 185-236. [CrossRef] [PubMed]

214. Altmanová, M.; Rovatsos, M.; Kratochvíl, L.; Johnson Pokorná, M. Minute Y chromosomes and karyotype evolution in Madagascan iguanas (Squamata: Iguania: Opluridae). Biol. J. Linn. Soc. 2016, 118, 618-633. [CrossRef]

215. Tegelström, H.; Ryttman, H. Chromosomes in birds (Aves): Evolutionary implications of macro-and microchromosome numbers and lengths. Hereditas 1981, 94, 225-233. [CrossRef]

(C) 2020 by the authors. Licensee MDPI, Basel, Switzerland. This article is an open access article distributed under the terms and conditions of the Creative Commons Attribution (CC BY) license (http://creativecommons.org/licenses/by/4.0/). 